\title{
9 Theurgy in Dionysius the Areopagite $^{1}$
}

\author{
Panagiotis G. Pavlos
}

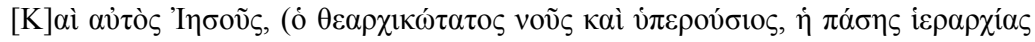

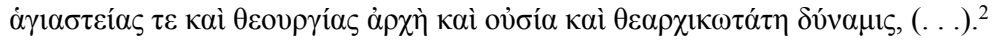

\section{Methodological concerns}

A common tendency in the study of Neoplatonism and its relation to Early Christianity is to examine the thought of Church Fathers, and other Christian thinkers, as the unknown author of the $C D$, on the premises of mere appropriation or adaptation of, or response to, or even distortion of, the originality of the Neoplatonic tradition. A particular instantiation of this tendency is to see the works of Dionysius the Areopagite through the lenses of the Neoplatonic currents of his times. ${ }^{3}$ Modern research offers relatively few opportunities of a per se consideration and evaluation of the Areopagitic contributions to Late Antique and Early Christian thought. ${ }^{4}$ It seems that a consensus has been established in the scholarship to resort to Proclean, or Iamblichean, or other Neoplatonic influences, in order to ground an enquiry into Dionysius' philosophical and theological paths. ${ }^{5}$

This practice becomes evident in the study of the central ritualistic activity

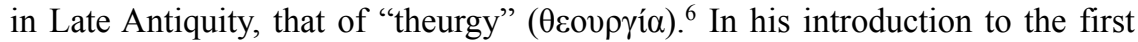
edition of Aristotle Transformed, in 1990, Sir Richard Sorabji made a substantial statement on the relation between Iamblichus and Dionysius. He said that "Pseudo-Dionysius appropriates Iamblichus' ideas for Christianity," and "he even applies his [Iamblichus'] word 'theurgy' to the Christian sacraments."" Moreover, in his article "Neoplatonic Theurgy and Dionysius the Areopagite" (1999) Gregory Shaw concluded, among other things, that: a) there is no real distinction between Iamblichean and Dionysian theurgy, b) a proper understanding of Iamblichus suffices for grasping the Christian theurgy of the Areopagite as an example of theurgy that is already defined in De Mysteriis, and c) Christian Ecclesiology develops at odds to the natural cosmos. ${ }^{8}$

The Introductory chapter to this volume offers several considerations about the relation between Platonism and Christian thought and touches upon the need for one to be aware both of the different grounds and the directions of their respective traditions. Therefore, I shall not enter here into further details. What I wish 


\section{2}

to remind the reader of though, is the need of being sensitive with respect to the premises that animate any discussion on the appropriation of Platonism by Christian thinkers. In spite of the temptation of reading the Areopagite Neoplatonically, there is an important Christian modification and variety of the metaphysical, cosmological, and epistemological principles that govern the development and structure of the Dionysian system. ${ }^{9}$

The implications of this for theurgy are enormous. It would suffice here to address just a crucial one. The understanding of the creation of the cosmos by one God, Triune in Persons but one in substance, annihilates the premise that governs the rationale of Iamblichean theurgy, as it is illustrated in passage T2 below. For there, Iamblichus says that "(...) the theurgic art discovers in general, in accordance with the properties of each of the gods, the receptacles adapted to

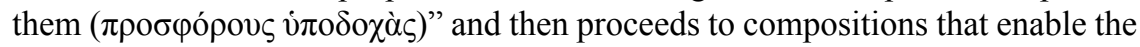
implementation of theurgy. So for Iamblichus the condition that allows for theurgy is that the sensible world bears similarities, or commonalities proportionate to the multitude of divine entities, of gods, and these suitable receptacles facilitate the theurgic process further. The Areopagite, however, moves far beyond Iamblichus' understanding, when he asserts that the provider of the theurgic myster-

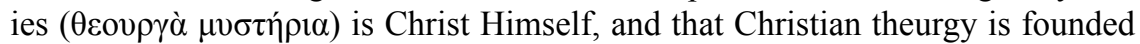
on a concrete, initial historical event which Dionysius calls "archetypal dinner"

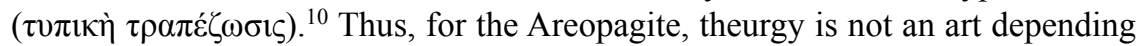
for its efficacy on the similarities of the sensible world to the world of gods, but a novel historical event associated with God's physical presence in the world and a certain new theandric activity. ${ }^{11}$

Moreover, there is no doubt that Dionysius purposely employs a vocabulary that is correctly acknowledged as Neoplatonic, mostly Proclean. ${ }^{12}$ But this, in my opinion, does not suffice to call him a Neoplatonist with all the respective consequences. There has been much discussion on this issue in the literature and many substantial points have been raised. My point here is a simple one: a vocabulary, a linguistic quiver does not bear any a priori qualification. It is just a language. And, indeed, Greek language, which supplies the Neoplatonic vocabulary, is a common achievement of Late Antique culture shared by people who may well adhere to different traditions, though living at the same time and place. ${ }^{13}$ For instance, at the same time as the works of Clement circulate in the Christian communities in Alexandria, Ammonius Saccas educates the founder of Neoplatonism, Plotinus. All I am saying is that linguistic affinities do not suffice to qualify a thinker either way. To make it more explicit: I do not mean that one should take the coexistence of Christian literature with Plotinus as evidence of their commonality. On the contrary. The example of the Alexandrine milieu wants to say that although we encounter the same technical language in use both by Christians and non-Christians, still the orientation of its use may well be different. ${ }^{14}$

There is a detail that could resolve the persistent question why Dionysius chose to use the distinctive vocabulary of Neoplatonism. The literature has viewed the possibilities that the Areopagite is either a Christian who purposely uses a Neoplatonic vocabulary as a "Trojan horse" to invade and demolish the construction 
of Neoplatonic theology and metaphysics in favour of Christianity; or even that he is a Neoplatonist who modified an originally Neoplatonic doctrine in order to manipulate the Christians in defence of Neoplatonism. ${ }^{15}$ There is a third possibility however, which, in my opinion, goes beyond the stance of regarding Platonism and Christian thought in such a competitive, even suspicious manner. Here is my thought. If Dionysius really is a Christian who relies on Scripture and who, although not a direct disciple of St Paul, however listens faithfully to him and aligns himself to him, then he should really imitate the Pauline attitude: "(. . ) and for the Jews I became like a Jew, in order to bring Jews with me; to those under the law I became like one under the law, to bring with me those being under the law; (...) I have become everything for everyone, so I might save some by all means."16 Here we have the straightforward statement of St Paul that defines his life and work. If Dionysius is a faithful disciple of St Paul, then he should definitely have adhered to his teacher's way of being and acting. This would be enough, I think, to explain why the Areopagite employs a Neoplatonic language. He addresses the people of his time by means of their proper tools of understanding. His strategy is not far away from St Paul's method of addressing the Athenians.

Another dimension of the Areopagite's intended use of Neoplatonic language is, I believe, worth mentioning, since it shows the multifaceted personality of this author, who apart from being a Christian, maintains Platonism in his capacity to embrace all that is good and beautiful. Plato says, in the Epinomis 987de: "we should also take that, whatever the Greeks receive from the barbarians, they elaborate it so that it becomes even better to its end." 17 This is a Platonic maxim that applies not only to the specific context of the worship of the stars, but-as any typical reader familiar with Platonism would easily confirm-Neoplatonic thought in its entirety. This maxim applied by Dionysius motivates him to gather all that is good and beautiful in the Greek tradition of his times, that is the Neoplatonic apparatus, and uses it in his synthesis. ${ }^{18}$ In other words, the Neoplatonic material

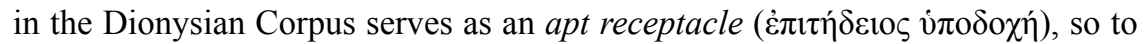
say, for the diachronic reception of the Pauline teaching in the Acts in front of the Areopagus. ${ }^{19}$ One may, of course, think that this argument is, at least, anachronistic, since the intellectual conditions of the fifth century are different: the decadence of Hellenistic thought in the first century, St Paul met with in Athens, should not be compared with the solid construction of the Athenian Neoplatonism. Even so, the Areopagite sees that the question on God remains unsolved even in his milieu of the fifth century.

In the light of the above, different contexts should also be paid attention to. One may think of Proclus' usage of the term $\pi \alpha \rho \alpha \gamma \omega \gamma \eta$ in a standard emanative context, in The Elements of Theology and elsewhere, which should not be confused with the Dionysian use in a rather creationist context. ${ }^{20}$ Thus, the claim that the Areopagite " (. . .) even applies his [Iamblichus'] word 'theurgy' to the Christian sacraments" should not be taken without qualification. There is indeed a certain amount of truth in Sorabji's claim; it is safe to conclude that Dionysius had read Iamblichus, ${ }^{21}$ or, in any case, knew about De Mysteriis through his overall relation with, and influence from, Athenian Neoplatonism, and therefore 
makes use of the same word. ${ }^{22}$ In addition, one could also count on there being no identifiable Christian influence on Dionysius on the matter. As Peter Struck notes, "unlike, say, the term theologia, which has not only Neoplatonic but also Patristic legacies, theurgy simply lacks other significant contexts than the narrow Neoplatonic one." ${ }^{23}$ But, despite the fact that Dionysian theurgy "is articulated in a variety of Neoplatonic terms especially reminiscent of the technical metaphysics of Proclus' The Elements of Theology," ${ }^{24}$ such an appropriation of the word "theurgy" by no means indicates that along with it the Areopagite receives, and reproduces, the specifics of a content elaborated in a Neoplatonic mindset.

\section{Iamblichean influences and provenance}

What I wish to do in this section is to provide the reader with some specifics that highlight the formation of the Iamblichean theurgic tradition, and which will allow her to discern similarities but also fundamental divergences between Iamblichus and Dionysius on the matter. There should not be substantial doubt about a certain amount of Iamblichus' background to the Dionysian development of theurgy. I suspect that the Areopagite might have been, inter alia, in the mind of John Dillon when the latter noted that "what is more worthy of attention, however, is the philosophical justification which he [Iamblichus] employs in defence of theurgy, and the importance which this has for the sacramental theology of the later Greek Christian Fathers. ${ }^{25}$ To summarise the common practices in the literature, there are at least two ways which may lead one to affirm Iamblichus' echoes in the Areopagite. One is to go through textual evidence; I would call that an "internal" verification of Iamblichus' influence on Dionysius. This has been persuasively implemented by Paul Rorem in his highly influential study on the Biblical and Liturgical symbols in the works of the Areopagite. ${ }^{26}$ Gregory Shaw has summed up Rorem's argument, in a part of which is found the position that the Dionysian division of three classes of worshippers is borrowed from Iamblichus, "who had distinguished three classes of souls and three forms of worship in the De Mysteriis." 27

The other way is to go through a rather simple consideration of the historical development of Late Antique philosophy, after Plotinus. I would call that an "external" grounding of Dionysius' Iamblichean background. Here is what I have in mind. With Plotinus we are introduced into a path of Platonism where

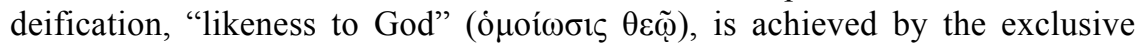
means of an intellectual activity proper that pulls the parts of the soul upwards, unifies the soul with the Intellect, and then both reach the completion of their conversion in a solitary encounter with the One. This is indeed a Platonic anticipation already expressed in Plato's Theaetetus 176b. Apparently, this Plotinian elaboration has left later Neoplatonists unsatisfied with regard to the destiny that Plotinus' interpretation of "likeness to God" reserves for matter and the "sensible" ( $\alpha i \sigma \theta \eta \tau o ́ v)$, in general. ${ }^{28}$ Iamblichus seems to be one of these dissatisfied people. One could recall, for instance, the respect and care with which he 
addresses "matter" ( Father and the Maker of all. ${ }^{29}$ I do believe that Iamblichus' positive attitude towards matter is definitely an additional good reason for the Areopagite to have shown interest in him. ${ }^{30}$

For Iamblichus $\theta \varepsilon$ ovp yí $\alpha$ is a term that "refers to the religious rituals-prayers, sacrifices, divinations-performed by the theurgist: it is one of a number of

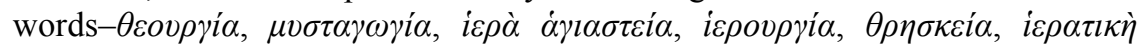
$\tau \dot{\varepsilon} \chi v \eta, \theta \varepsilon o \sigma o \varphi i \alpha, \dot{\eta} \theta \varepsilon i \alpha$ غं $\pi \imath \sigma \tau \dot{\eta} \mu \eta$-which have all more or less the same meaning and which are frequently simply translated théurgie by E. des Places in his edition of Iamblichus' de Mysteriis." 31

\section{Theurgy and epitēdeiotēs}

A core idea that shapes the grounds for the development of Iamblichean theurgy is the following. Divinity is present in the cosmos in such a way that it permeates the worthiest men to become its agents, in a manner proportional to their

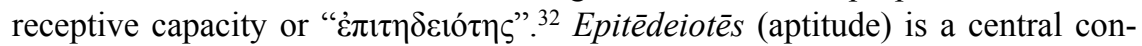
cept in Late Antique thought. ${ }^{33}$ It is already present in the thought of Clement of Alexandria and Alexander of Aphrodisias. Both of them resort to it in exemplifying the relation between Aristotelian potentiality and actuality. It is presumably through Alexander that the concept was received by Plotinus, who elaborated it further, and since figures constantly in the accounts of Late Neoplatonists, ${ }^{34}$ while it receives new content in the thought of the Areopagite whose formulations found fertile grounds in the works of St Maximus the Confessor. ${ }^{35}$

In its metaphysical context, epitédeiotēs amounts to a kind of prerequisite for the reception of divinity. ${ }^{36}$ From this point of view, it is safe to assert that Iamblichus' use of the concept in his theurgic context remains within the Neoplatonic mainstream where epitēdeiotēs is-since Plotinus-associated with a passive potency. ${ }^{37}$ That is, it is associated with a capacity of an entity to undergo a change caused by an agent. ${ }^{38}$ I say "is associated" and not "is identical" precisely

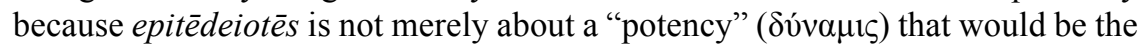
necessary condition for an alteration, transformation or change; rather, it is about that which gives potency to the "green light" for actualisation. In other words, I agree with Sambursky who has argued that epitédeiotes is the "sufficient" (not the "necessary") condition for a change. ${ }^{39}$ If that is so, then epitédeiotēs is additional to a correspondent potency.

But with Iamblichus, things seem to get a bit paradoxical at this point. It is very interesting to see how he exemplifies this prerequisite for the reception of divinity in his theurgic account, by focusing on the role water plays in preparing one to receive divinity. His case study is the oracle at Colophon:

[T1] (. . .) [F]or the divine does not permeate what partakes in a fragmented $[\delta 1 \alpha \sigma \tau \alpha \tau \tilde{\omega} \zeta]$ and divided $[\mu \varepsilon \rho \imath \sigma \tau \tilde{\omega} \varsigma]$ manner, but it is by exercising its power from without, and illuminating the spring, that it fills it with its own prophetic power. Still, not every inspiration that the water gives is from the god, but 


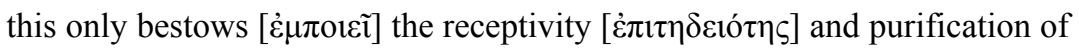
the luminous spirit in us, through which we are able to receive the god [ $\delta$ ' '

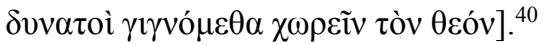

There is something remarkable in this passage. For here Iamblichus seems to revert the order: "potency" led by "epitédeiotēs" into "accommodating divinity" I referred to above. In his theurgic account, the material elements seem to be welcome into a rather paradoxical play. Namely, to provide externally to the patient the potency for the reception of divinity, a potency that - if my interpretation is correct - was not present to the subject before. ${ }^{41}$ If this is so, and if this is not just an Iamblichean posture but rather a distinctive characteristic of pagan theurgy, then one can have an additional explanation of why Plotinus would never consider seriously the detrimental philosophical consequences of theurgy. In any case, and apart from the theoretical problems the prioritisation of matter raises to the intellectual pillar of Neoplatonism, what becomes evident above is that Iamblichus' theurgic account is built upon the capacity that entitieswhether ensouled or inanimate-obtain by means of material-theurgic-objects, to accommodate divinity. This Iamblichean understanding of aptitude seems to differ from Dionysius' for whom the ecclesiastical hierarchy and order is built

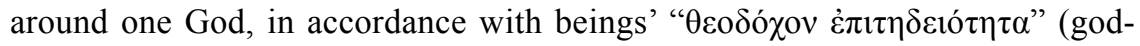
receiving aptitude), the latter not depending on theurgic material elements. ${ }^{42}$ Interestingly, but not surprisingly, Iamblichus never describes epitédeiotess as "god-receiving."

\section{Theurgy as techne}

Moreover, the reality of Iamblichus' theurgy expands over a rationale that is reflected in his description of the function of theurgic art:

[T2] Observing this, and discovering in general, in accordance with the

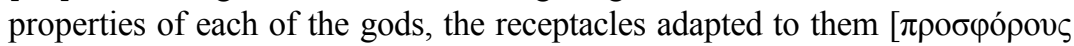
vं stones, plants, animals, aromatic substances, and other such things that are

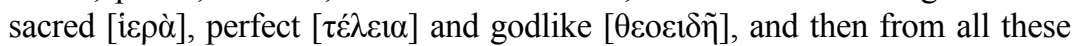

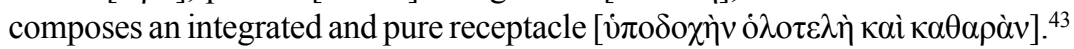

As far as I can see, Iamblichus' theurgic attitude towards sensible objects seems to have no parallel in Plotinus' Enneads. Speaking so, by no means would I come to question Plotinus' sensitivity towards living beings and nature in general. There is plenty of evidence offered by Porphyry in his Life of Plotinus that confirms the unique qualities of Plotinus as a man with care for sensible beings. ${ }^{44}$ Unlike the theurgic tradition, in the view of Plotinus, ${ }^{45}$ the material world is something to be left behind (or beneath). Irrespective of how one would read this passage, whether one would go for crediting Iamblichus with an a priori 
qualification of material objects as "sacred," "perfect" and "godlike," or would agree that this qualification occurs after magical spells have transformed the constitution of the objects so as to become divine, ${ }^{46}$ one thing is clear. For Iamblichus material objects are a substantial component of his theurgic actualisation of deification. What is not quite clear though, is how Iamblichus has come to acknowledge the divine-likeness $(\theta \varepsilon 0 \varepsilon i \delta \varepsilon 1 \alpha)$ of all these materials. Perhaps, an answer could be found behind his alignment with Egyptian theurgy, a distinctive characteristic of which were to "imitate the nature of the universe and the creative activity of the Gods." ${ }^{47}$ However the case may be, one would be reasonably tempted to bring the Areopagite closer to Iamblichus rather than to Plotinus, in this regard.

As every art is performed by an artist, "theurgic techne $\vec{e}$ needs an agent too. This is the "theurgist" ( $\theta \varepsilon$ cov $\rho$ ó $\varsigma)$. For Iamblichus, a theurgist is a purified human being, an initiated earthly agent focused on intellectual life, who enacts divine and divinising works upon beings:

[T3] Those, on the other hand, who conduct their lives in accordance with intellect alone and the life according to intellect, and who have been freed from the bonds of nature, practise an intellectual and incorporeal rule of sacred procedure in respect of all the departments of theurgy. ${ }^{48}$

Note the significance of this passage. For it shows how difficult, even superficial, it would be to detach theurgy from the fundament of Neoplatonism, that is, the intellectual activity. ${ }^{49}$ Clearly, Iamblichus builds upon Plotinus by asserting that the precondition for becoming a theurgist is the achievement of a proper intellectual life. ${ }^{50}$ Purification is understood as the detachment from earthly matters by means of a life governed by the intellect. Such a purified being, a theurgist, is befitted with the power of the unutterable symbols ( $\sigma v v \theta \eta \mu \alpha \tau \alpha)$, which transform him, as it were, from an ordinary human being into a divine being, and enable him to perform acts with powers alien to "common" mortals:

[T4] The theurgist, through the power of arcane symbols, commands cosmic entities no longer as a human being or employing a human soul but, existing above them in the order of gods, uses threats greater that are consistent with his own proper essence (...). ${ }^{51}$

The basic component, or characteristic, of this "ontological upgrade" of the theurgist is that he receives a power belonging to gods, which renders him nothing other than a divine agent. Yet, such a person remains a man, a human being, after the temporary theurgic deifying process is completed. ${ }^{52}$ This last remark brings Iamblichus' understanding of a theurgist in perfect contrast to the Areopagite's. For the latter, as it is evident in passage T6 below, does not speak of a temporary theurgic effect taking place on the theurgist but of the permanent novel theandric activity of God having become man. 


\section{Dionysian novelty}

At the opening of this chapter it was said that the term $\theta \varepsilon o v \rho \gamma i \alpha$ is exclusively used by the Areopagite in a twofold manner. It refers a) to the works of Christ in His earthly historical presence, and b) to the whole divine providential, creative, sustaining, and divinising divine activity and work of God. For Dionysius theurgy and its derivative "theurgist" ( $\theta \varepsilon$ ov $\rho \gamma o ́ \varsigma)$ applies exclusively to Christ, the GodMan. A being perfectly human and, at the same time, perfect God - that is to be acknowledged in two natures "inconfusedly" ( $\dot{\alpha} \sigma v \gamma \chi v \dot{\tau} \omega \varsigma)$, "unchangeably"

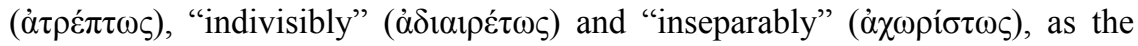
Council of Chalcedon had established. ${ }^{53}$ So the first case is about the source of the Christian sacramental tradition, in which the predominant position is reserved for

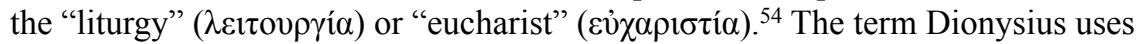
is " $\sigma u ́ v \alpha \xi ı \zeta$ " (gathering-together). ${ }^{55}$ The core meaning of the liturgy develops on the grounds of the reiteration of the initiative established by Christ with the Last Supper. The general scope of the liturgical reality in the works of the Areopagite is the "celebration of the acts of God, especially, and centrally the divine activity manifest in the Incarnation of Jesus." 56 The Eucharist along with the baptism and the sacrament of the oil is the first sacramental triad that expounds the services of the ordination, the monastic consecration, and the funeral. ${ }^{57}$

Indeed, a careful reader of the Corpus would easily come to confirm these two directions and would have to admit that, consequently, for Dionysius a theurgist could not be anyone else than Christ Himself. It becomes immediately obvious that the first dimension of Dionysian theurgy brings about the much-debated topic of Christology in the works of the Areopagite. ${ }^{58}$ I shall abstain from entering into it here, not only because this would lead us far off the scope of the present chapter, but also because the treatment of this question has nowadays arrived at a positive conclusion favouring the definite Christological character of the Corpus. ${ }^{59}$ Yet, I shall focus on some passages of strong Christological taste that substantiate my argument. In the Ecclesiastical Hierarchy Dionysius shows in a quite straight forward way that theurgy and everything related to it stems from, depends on, and associates with Christ Himself:

[T5] For thus, as the Word of God [ $\theta \varepsilon 0 \lambda \mathrm{o} \gamma i \alpha]$ has taught us who feast at his Banquet, even Jesus Himself-the most supremely Divine Mind

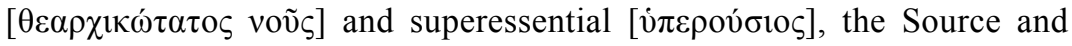

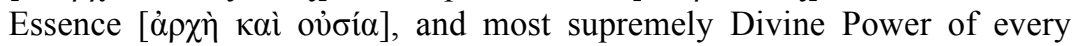

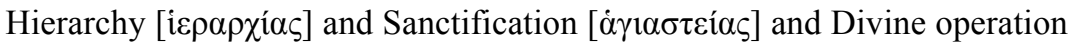
[theurgy, $\theta \varepsilon o v \rho \gamma i \alpha \varsigma$ ]-illuminates the blessed Beings who are superior to us, in a manner more clear, and at the same time more intellectual, and assimilates them to His own Light, as far as possible (. . .). ${ }^{60}$

This passage confirms that Dionysius in no way promotes a multitude of gods that distribute a certain theurgic capacity to their recipients through intermediate entities or material items, as the water of the oracle of Colophon. Against the 
Neoplatonic multiplicity of higher and lower divine entities that bestows theurgic properties on worthy men by means of material items, here we have a straightforward statement that the principle, source, substance, and power of theurgy is one Triune God, ${ }^{61}$ the God-Man $(\theta \varepsilon \alpha ́ v \theta \rho \omega \pi \circ \varsigma)$, Christ himself, the source of all powers and activities. One may rightly object that the term theanthropos is not employed by Dionysius. The Areopagite, however, does acknowledge identifica-

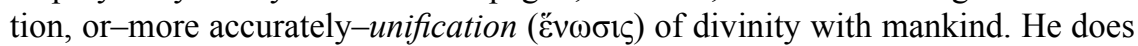
so in several ways throughout his Corpus, the most characteristic perhaps, being the debated conclusion of his 4th Epistle.

[T6] For, even, to speak summarily He was not man, not as not being man, but as being from men was beyond men, and was above man, having truly been born man, and for the rest, not having done things Divine as God, nor things human as man, but exercising for us a certain new God-incarnate

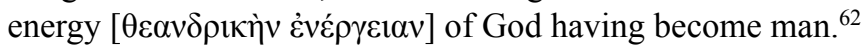

Had Dionysius not used "theurgy" anywhere else in the Corpus, passages T5 and T6 alone would suffice to demonstrate the absence of Neoplatonic orientation in

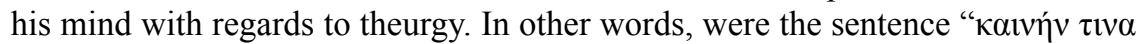

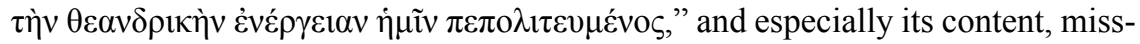
ing from the works of the Areopagite, any attempt to claim novelty in the manner he regards theurgy would be totally hopeless. This new "theandric activity," that since the 1960s has caused a scholarly debate and offered reasons to regard it as an "objective link between Dionysius and Proclus," as Henri-Dominique Saffrey had proposed, ${ }^{63}$ is repeatedly acknowledged in several places throughout the $C D$. I take one passage from the Celestial Hierarchy to be of relevance here:

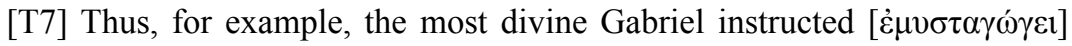
Zachariah, the Hierarch, that the son who was to be born to him, beyond hope, by Divine grace, should be a prophet of the God-incarnate work of the Lord

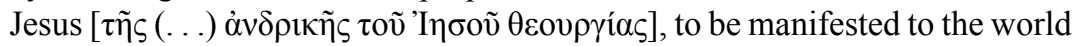
for its salvation, as becomes the Divine goodness; and he revealed to Mary, how, in her, should be born the supremely Divine mystery of the unutterable

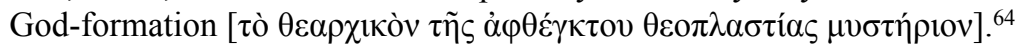

This passage depicts, as a matter of fact, the prophetic vision of an event without equivalent in the history of mankind and the cosmos; namely the entry and presence of God in history, in the Incarnation of Logos in the person of Jesus the Son of God, the Son of man. The Areopagite's persistence on describing with theurgy the acts of Christ is evidenced in another significant passage from the Ecclesiastical Hierarchy, which is concluded by the Dionysian view of theurgy as the consummation of theology:

[T8] (. . .) the one [Old Testament] affirms the theurgies of Jesus to come

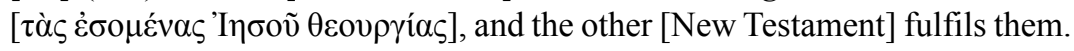


Just as the former wrote the truth in figures, the latter demonstrates its pres-

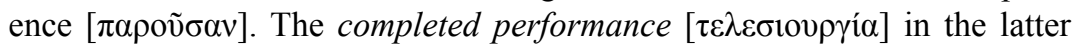
confirms the truth of things foretold in the former, and theurgy is the consum-

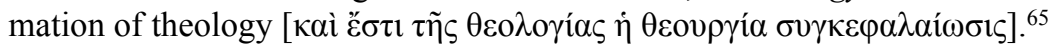

This is about a particular, concrete frame, introduced by the Areopagite, which leaves little room for holding the view that Dionysius thinks of theurgy in Neoplatonist, whether Iamblichean or Proclean, or any other terms. What is common in passages T5-T8 is the strong Christocentric background of the Dionysian concept of theurgy. Dionysian Christocentricity, overall, and with regards to theurgy, was pointed out by Fr. Andrew Louth who affirmed that "Dionysius seems much more Christocentric than has often been allowed." 66

The second frame from within which Dionysian theurgy emerges is Dionysius' approach to the knowability of God and all that comes along with it about the knowledge of the cosmos as made by God. In a wonderful summary of Dionysius' approach Fr. Georges Florovsky helps to reveal the springs of Dionysian theurgy:

God is revealed and acts and is present in creatures - a creature exists and abides and lives by virtue of this Divine Omnipresence. God is present in the world not in his own essence, which always remains unattainable, unknowable, and ineffable, but in his 'works' and his goodness, which come from the incommunicable God as an abundant current and which gives communion to what exists. He abides in the world in his 'creative emanations' and 'beneficial providences,' in his powers and energies. In his self-revelation to the world, God is cognisable and comprehensible. This means that God is comprehensible only through revelation. ${ }^{67}$

The Areopagite can speak about theurgy, since he acknowledges that God has revealed Himself. This revelation entails divine action, which precisely points to the understanding of $\theta \varepsilon$ ov $\rho$ í $\alpha$ as ergon theou where the "theou" is a subjective genitive, as we shall see below. Strikingly, Florovsky reveals another-hidden up to now-interpretation of Dionysian theurgy. For if creatures "exist" and "abide" and "live" by virtue of the "Divine Omnipresence," then creatures are manifestations of theurgy as well. We, human beings, are theurgic "products." This is novel indeed. For, even if one would come to argue that the idea of Divine Omnipresence is not an Areopagitic innovation, but rather an old Platonic conception detailed, at least, by Plotinus, in Enneads VI.4 and 5, Florovsky makes perfectly clear the distinction, implicit in Dionysius, between divine essence and activity, which differs from Plotinus' doctrine of double activity.

In Plotinian theology, God, the One, has (or, better, is) a double activity. ${ }^{68}$ The inner activity of the One would correspond to the divine essence Florovsky refers to. But the Plotinian illustration of the external activity of the One leaves no doubt that-as a matter of fact-it is about the "essence" of the One that overflows. The external activity that emanates is nothing other than an excess of the very inner 
activity. So for Plotinus there is no distinction between divine essence and activity, because the cosmos comes to be emanatively, eternally, and therefore necessary. For Plotinus there is no such a precosmic state (or, better, non-state) "when there was" no external activity of the One. Only a doctrine of creation "saves" God's freedom from the necessity of identifying creation with His essence. This insight is crucial, I believe. For, taken to its extreme, shows that, from the Dionysian Christian point of view, there is no real "theurgy" in Neoplatonism. ${ }^{69}$

\section{Theurgy as goodness}

Florovsky does not forget to mention divine Goodness, which indeed pervades the Corpus, and is the main theme of Chapter 4 of the Divine Names. "A $\gamma \alpha \theta$ ó $\tau \eta \varsigma$ " is a divine name that has a long history before Dionysius and which, in the cosmological context, links him directly with Plato's Timaeus. What is significant in connection with Dionysian theurgy is that the Areopagite offers another hint of the divine origin of theurgia by making up a term similar to it: "agathurgy"

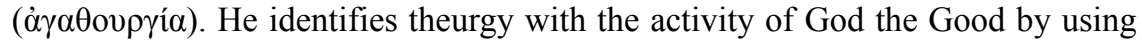

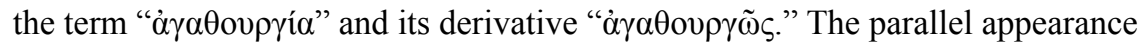
of theurgy and "agathurgy" is frequent in several passages, especially in the $E H$, where, according to Thesaurus Pseudo-Dionysii Areopagitae, agathourgia, and

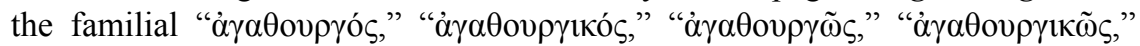
appear in total about 14 times. $^{70}$ I do not see any parallel to this Dionysian word coinage in Iamblichus' De Mysteriis. At least, there is no such a term registered in the Index to Clarke et al. edition. So for the Areopagite, it is God the Good who acts theurgically. Thus every theurgy is an agathurgy, a divine work agathurgically enacted and manifested. One may comment that all the above novel Dionysian terms fall under the need to examine their syntactical relation as in the case of theurgy. That is, whether agathurgy is about a work of the Good or a work that aims at the Good. The contexts where agathurgy and the like appear make no room to consider the second possibility. I think we should take है $\rho \gamma$ ov $\alpha \gamma \alpha \theta$ ov in

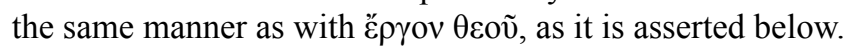

Moreover, Florovsky continues, "there is, however, another revelation. This is the world itself, for in a certain sense the entire world is a certain image of God and is entirely permeated with Divine energies. And in God there is a 'creative prototype' of the world, through participation in which the world has objective reality." 71 For Dionysius the entire world is a manifestation of God. It is indeed a "theophany." Earlier, I said that the Iamblichean notion of theurgy expands over the idea that divinity is present in the cosmos in such a way that permeates the worthiest men to become agents of her, in a manner proportional to their receptive capacity. If that is the case with Iamblichus, then what makes a difference with regards to theurgy in Dionysius?

Apart from what has been already argued about the Neoplatonic multitude of divine entities versus the Dionysian Triune God, I think that there is something more to be extracted by Florovsky's illustration. That in God there is a "creative prototype" prompts us to think that the created cosmos has a telos, an aim to 


\section{2}

reach. This aim cannot be reached but through participation in this divine reality which unfolds not only the real dimension of the cosmos that is the divine image imprinted on it, but also the fulfilment of the cosmos, which is the dynamic status of divine likeness. Divine likeness, in turn, is possible only by participation,

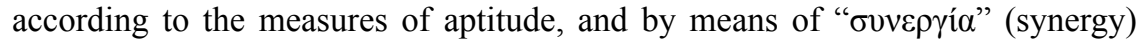
between man and God..$^{72}$ have the impression that all this leads us far away from the limits Iamblichus had, indeed succeeded to reach, with his development of theurgy; there is indeed a very noteworthy development from Plotinus to Iamblichus, considering that for Plotinus we indeed love and need the One, but It is not interested in us or "loves" us.

In chapter 4 of the Divine Names the Areopagite employs the terms $\theta \varepsilon i ̃ \_\varsigma$ है $\rho \omega \varsigma$

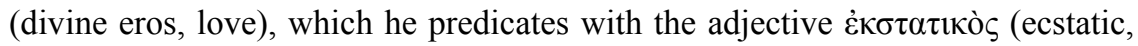
self-emptying). This providential love of God is the very agitator, the source of Dionysian theurgy. "Divine love envelops the lovers like a kind of ecstasy - है $\sigma \tau \imath$

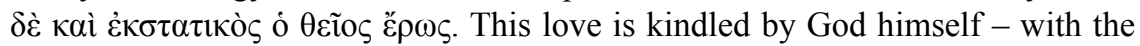
tender breath of his goodness." ${ }^{.73}$ If the overall aim of Dionysian theurgy is to render everyone God and if Florovsky is correct in that "this [divine] love is also the beginning of order and harmony - a simple and self-propelled force which draws everything towards unity, towards 'a certain unity-creating dissolution',",74 then for the Areopagite theurgy is firmly connected with God's love for the mankind and His "philanthropy" ( $\varphi$ i $\alpha \nu \theta \rho \omega \pi i \alpha){ }^{75}$

\section{Theurgy and hierurgy: "Yuvos and Aĩvo $\varsigma$}

In the Areopagite's thought there appears another distinctive element that stresses his distance from mainstream Neoplatonism. For whenever Dionysius resorts to hymns-and he does so quite often-he does not suggest worshipping a mundane entity or any other kind of activity, whether mundane or derived from superior or intermediate divine entities. Rather, he distinguishes between divine and human activity in a manner without Neoplatonic parallel. For him, divine activity is to be "hymned" ( $\dot{\mu} \mu v \tilde{\eta} \sigma \alpha l)$ as "theurgy," whereas human activ-

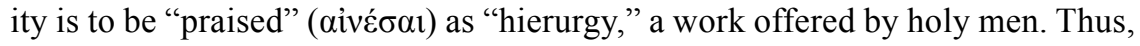
theurgy corresponds to a transmission of God's divine activity and hierurgy to its partaking. ${ }^{76}$ The last two notions form the reality of participation both in its sacramental implementation and the wider Christian metaphysical contours. In other words, the Dionysian act of "hymnessis" is about venerating the superabundant love that renders the "substantially unparticipated" benevolently and philanthropically participable:

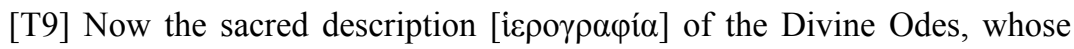

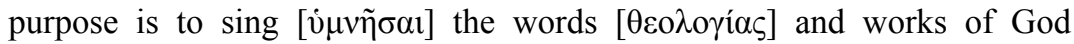

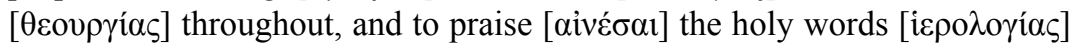

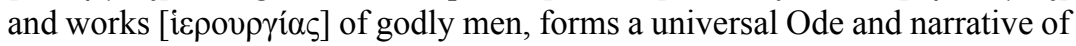
things Divine, in those who inspiredly recite it, a habit suitable for the reception and distribution of every Hierarchical mystery. ${ }^{77}$ 
The Dionysian concept of participation consists of two distinct parts: "transmis-

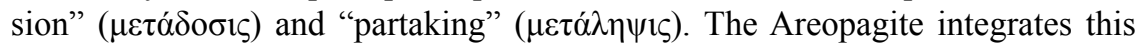
originally Neoplatonically established pair of components that constitute participation in a twofold manner. The one aspect of this integration relates to the wider metaphysical participatory contours. The other focuses on the specific sacramental tradition and reality of the Church, which is rooted back in the "archetypal

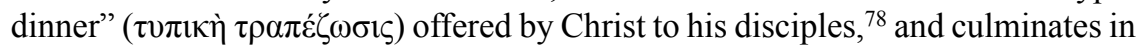
the Divine Liturgy, which "consists not of sacred words but of sacred action."79 As fr. Vasileios Gontikakis puts it, in the Liturgy "we do not speak but act." ${ }^{\circ 0}$ At the same time, Divine Liturgy is not only "a celebration of the acts of God, especially, and centrally the divine activity manifest in the Incarnation of Jesus," but also the paradox, albeit real, mysterious, hyper-temporal presence of Christ in history, as promised by Christ himself: "in a little while the world will no longer see me, but you will see me; because I live, you will also live." ${ }^{\text {"1 }}$ Both the above aspects are valuable in indicating the new dimensionality the notion of theurgy receives in Areopagite's thought.

Though Dionysius praises the reality of participation, he does not think of theurgy in Neoplatonic terms. For what becomes evident in passage T9 is that, for the Areopagite "transmission" ( $\mu \varepsilon \tau \alpha \dot{\alpha} \delta \sigma \sigma \iota)$ is an act of "theurgy" ( $\theta \varepsilon o v \rho \gamma i ́ \alpha)$,

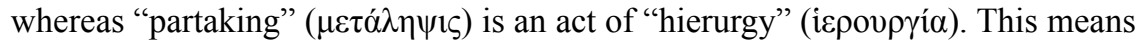
that when Dionysius employs the term theurgy, he does not mean worshipping, let alone performing a mundane activity; not at all. Rather, with $\theta \varepsilon o v \rho \gamma i ́ \alpha$ he refers to the historical divine acts of Christ and their reiteration within the liturgical celebration. This is what Louth underlines by saying that "Denys seems to make a clear distinction between $\theta \varepsilon o v \rho \gamma i \alpha$, which refers to the divine acts praised in the liturgy, and the celebration of the liturgy itself, for which his favourite term is

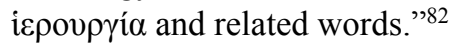

So the Areopagite introduces a radical distinction between divine and human activity. It is the divine activity in all its manifold presence that deserves to be

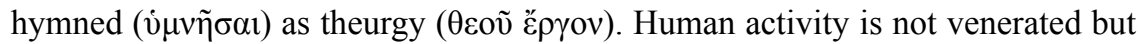

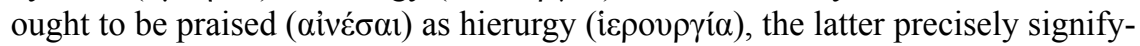
ing a work offered by holy men. At best, what one could conclude at this point with regards to Iamblichean theurgy, is that what Iamblichus postulates with his $\theta \varepsilon o v \rho \gamma i \alpha$ is nothing other than the Dionysian activity of hierurgy. ${ }^{83}$ This is the only possible correspondence between the two.

For Dionysius, it is God himself, the One Trinitarian God, and not a multitude of Gods, who acts and transmits His gifts, the divine gifts. These gifts are received and further transmitted to the host of the members constituting the ecclesiastical hierarchy through the act of hierurgy. One could make the case that this also applies to Neoplatonism. In Proclus, for instance, it is the triune One, Mind, and Soul that projects theurgic energies below, mediated by subordinated gods and their prevailing henads. But this similarity would be only apparent. Not only because Proclus' system is fundamentally polytheistic. But, because, as Norman Russell notes, "the philosophical ascent of the human soul, even if assisted by theurgy, is essentially an intellectual process. In Proclus, the tapping into the 
divine power is by appropriate rituals," while for Dionysius, "the theurgical activity that enables the believer to benefit from it [in other words, to partake, through hierurgy, of the divine gifts] is at its deepest level the very activity of the incarnate Christ that makes the sacraments efficacious." ${ }^{" 84}$ One should pay attention to the fact that, for the Areopagite, God does not have to be requested - in the symbolic manner a Neoplatonist would evoke divinity ${ }^{85}$ - in order to proceed to the transmission of his gifts. Such a transmission is voluntary and implemented in the sacrament of the Eucharist as a reiteration, nonetheless singular and unique, of the specific divine initiative that was initially-and, again, voluntarily-historically established by Christ in the Last Supper. If that is the case, then the claim that "Dionysian (and Eastern Church, for that matter) sacramental theology is thus fundamentally similar to Hellenic theourgia in that both use material symbola to harness divine energeia, but there is a subtle shift in terminology as between Dionysius and his Neoplatonic predecessors," $" 86$ is not very accurate. The material symbols are not used because of an initial belief that they have theurgic properties, and therefore attract the divine energy. Rather, it is Christ Himself who acts in the Liturgy as He acted in the Last Supper and transforms the bread and the wine into His flesh and blood. So long as the bread and wine are considered as mere symbols and not seen, paradoxically, as flesh and blood, there is, indeed, no difference between Iamblichus and the Areopagite with regards to theurgy.

There are at least two more significant distinctive characteristics of Dionysian theurgy. The one is about a distinction and the other is about an identification. While for Iamblichus theurgy and hierurgy are concepts equivalent in their content value, for the Areopagite theurgy is the prerequisite of hierurgy. There is no hierurgy without theurgy. This is made perfectly clear in the Ecclesiastical Hierarchy, where Dionysius clears out that "thus, the hierarch is united with the divine and having hymned the holy theurgies performs the most holy and leads to vision what has been hymned." ${ }^{87}$ The implementation of the hierurgic activity of the hierarch presupposes the recognition and veneration of a great number of holy theurgies that Dionysius admits he can hardly sufficiently enumerate.

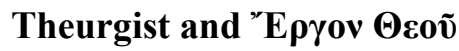

It has been debated in the literature whether the author of the $C D$ could be regarded as a $\theta \varepsilon o v \rho \gamma o ́$, and what is the syntactical relation between the two components of the compound $\theta \varepsilon o v \rho \gamma i \alpha$ ( $\theta \varepsilon$ ò first question by the aid of the following distinction. Namely, of whether to be a theurgist is a substantial (ovं $\sigma \tilde{\omega} \delta \varepsilon \varsigma$ ) idiom of someone or simply an accidental one ( $\sigma \nu \mu \beta \varepsilon \beta \eta \kappa o ́ \varsigma)$. Earlier in this chapter it was said that Iamblichus' Neoplatonic theurgy is qualified as an art ( $\tau \dot{\varepsilon} \chi v \eta)$, and therefore, the theurgist is considered as an artist as well; one who has learnt to perform the theurgic art. We have seen that for Iamblichus a theurgist is a mere human being that has reached a proper intellectual end and has been purified by certain specific ritualistic processes. The fact that not all human beings are theurgists but only those who have been ritualistically transformed clearly indicates that an Iamblichean theurgist should 
be thought of kata symbebēkos. ${ }^{88}$ One may reasonably argue that this distinction comes in contrast to what Louth has asserted on the matter. His take is that " $\theta \varepsilon$ covpró, , in pagan use is usually a noun, meaning a theurgist, one who practices theurgy." But, he adds, "in Denys it is always an adjective." ${ }^{89}$ This comment does not, in fact, contradict the distinction I am making.

The Areopagite's hierarchical conception of the cosmos is an "open" system; that is, a system reflecting an absolute freedom inserted into a dynamic cosmos that is likely created out of nothing. ${ }^{90}$ The entire cosmos is a divine work, a theurgy, a product of divine activity that came to be out of nothing. On the basis of the earlier discussion of the presumed Dionysian creatio ex nihilo, the world should be seen not as creation out of God's "essence" (ov̉oía) - a view developed in the Mediaeval revival of Neoplatonism, divine essence taken as non-being -

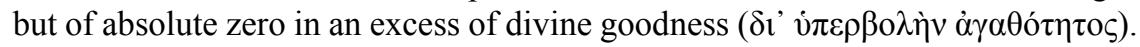
God did not fuse His divine essence to the world in creating it. Rather, all that is made is made as a manifestation and actualisation of divine power. Hence, God remains hidden from the cosmos. Yet, He is present through His activity. This activity is theurgy, a "power," a "quality," a "manifestation" of Him who remains substantially unknown. ${ }^{91}$ Had there been no Incarnation, one could not have been able to discern Christ as the kat'ousian theurgist. But the specific aspect of Dionysian "theophany" as Incarnation comes to unveil the agent of this extraordinary theurgic power. This "revelation" shapes the grounds of deification in Dionysius

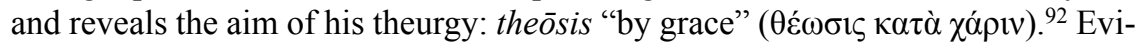
dently, it appears a way to positively assert Dionysius, that is a mere human being, as a theurgist but only in the scope of deification, for which a necessary condition is the synergy between God and man. ${ }^{93}$

I move now to the second question of this section, which has been nicely illustrated by Gregory Shaw as "Who is the Subject of the Ergon Theou"?94 Apparently, after the last concept mentioned in the previous paragraph, things become rather trickier than one may have thought. If I wished to enigmatically illustrate what I believe Dionysius would have to answer, I would suggest that Shaw's initial question should now become "who are the subjects of the Ergon Theou." But let us have things in order. The question is about who really the agent of theurgy is, and consequently, who is the receiver of it. This question has an interest and that is that the answers proposed in the scholarly literature highlight the divergences between Dionysius and Iamblichus. Shaw discusses Rorem's argument that the word theos is an objective genitive in Iamblichus' use of $\theta \varepsilon o v \rho \gamma i$; t that is, theurgy is about a work offered, or addressed to God. ${ }^{95}$ Then, he sets forth Louth's modifications of Rorem's argument, which stand by the same line, but which, I have the impression, give a greater joy to Shaw than Rorem's position does. Finally, he presents some rather psychological reasons on the impossibility to take the subject of ergon theou to be a human, in Iamblichus, as argued by Annick Charles-Saget and John Rist. I am inclined to admit that, if Christ is the only one who Dionysius considers as the real theurgist, then clearly this genitive theou should be a subjective one. This comes out from the Dionysian vision of the cosmos as theurgy, as well. Now, the fact that Dionysius innovatively introduces 
the concept of synergy between God and man in the salvific/deifying process prompts one to think that synergy necessarily entails the inclusion of man as a second subject of theurgy. It would need a separate study to advance this idea further. But I could simply ground my argument upon this: the lives of the Saints of the Church, and primarily the Acts of the Apostles, show that they should be included as co-subjects to ergon theou, beyond their role as mere partakers of the divine activity. ${ }^{96}$ As a matter of fact, they are (active) theurgists as well, healing people from bodily and spiritual bonds. ${ }^{97}$ So, synergy with God effects to a Godlikeness that bears along all capacities and implementations of God's theurgy in the cosmos.

\section{Critical remarks}

I wish to add some remarks that derive as a corollary from what has been said so far and come in support of the claim about the misinterpretations the Dionysian notion of theurgy has received. As it is often the case, misinterpretations of a certain text may be due to a kind of praising the textual evidence along with a selective concealment of passages that neutralise what is distinctive in a specific context, whether Christian or Neoplatonist. It has been argued in the literature that distinguishing between Iamblichean and Dionysian theurgy is a result of a caricature of Iamblichean theurgy, made by many theologians and other scholars. This claim pairs with the belief that one has only to understand properly Iamblichus' theurgy as it is presented in De Mysteriis, in order to regard theurgy according to the Areopagite as an example of theurgy that appears in Iamblichus. Gregory Shaw, in his substantial comparison between Iamblichean and Dionysian theurgy, aims at refuting "the false distinction between 'pagan' and Christian theurgy" and suggesting that "such distinctions reflect more apologetic interests of scholars than an accurate reading of the evidence." 98

There is a, if not many, typical trap here. That is, to consider the evidence of an apologetic as inferior to what one would regard and qualify as an accurate reading of the evidence. But evidence qua evidence is never sufficient for any conclusion unless it is anticipated by certain philosophical and/or religious disposition and frame of reference. Thus, the accuracy of the evidence should be evaluated on the grounds of the tradition that has produced it. This means that Iamblichus should be evaluated "Iamblicheanly" whereas Dionysius "Dionysianly." Otherwise, there is nothing that can hinder the reversion of Shaw's argument "when Iamblichean theurgy is properly understood, the Christian theurgy may be seen as an example of the same kind of theurgy that Iamblichus defined in the De Mysteriis," 99 into, for instance, "when Dionysian theurgy is properly understood, Iamblichean theurgy may be well seen as a material that served as the receptacle of Christian God's Revelation.” Moreover, the term "apologetic" ( $\dot{\alpha} \pi \mathrm{o} \lambda \mathrm{o} \gamma \eta \tau \eta \dot{\zeta})$ refers to a person who feels the urge to provide an account in defence of a truth that is offended. As such, an axiological judgement against the apologetics is veiling rather than unveiling a truth, unless this truth should be credited a priori and exclusively to a specific (say non-apologetic) mindset. ${ }^{100}$ It is definitely correct 
though, what Shaw suggests, namely that "scholars of Neoplatonic theurgy could learn a great deal from Dionysius about the specifics of theurgic ritual that Iamblichus does not discuss." 101 Yet, this suggestion adheres in its premise to the assumption of an essential commonness between Iamblichean and Dionysian theurgy. What one learns precisely through the Areopagite, is not about any Neoplatonic telete but, rather, about the theurgy of Him who was announced to the Athenians at the times of the, homonymous to our hidden author, higher officer of Areopagus. It is true that Iamblichus does not discuss what we find in Dionysius, because Dionysian theurgy is grounded on a reality entirely alien to Iamblichus. Such reality consists inter alia of the Baptism of Jesus in the Jordan River, the Archetypal Dinner, the Transfiguration on the mount Tabor, and the unintended transferring of healing power from Christ to the bleeding woman, in the midst of a crowd congregation. All these instances should be boldly contrasted to Iamblichean, or Proclean, theurgy. ${ }^{102}$

Moreover, Shaw seems to project on Dionysius an Iamblichean, typically Neoplatonic, view on deification. In his words, “(. . .) we must follow Dionysius in seeing the liturgy as theurgy, a rite that effects a cognitive, perceptual, and ontological shift so profound in receptive participants that it culminates in theossis, the deification of the soul." ${ }^{103}$ Indeed, deification of the soul is the core of Platonic likeness to God. Nevertheless, this is a statement far from illustrating the aim of Areopagite's theurgy, which is deification of the body-soul compound of the human being. ${ }^{104}$ It would be impossible to exclude the body from the unquestionably Christian approach of Dionysius to deification. So even if it would be correct to assert that "Iamblichus was the first to provide a comprehensive rationale of the pronounced interest, among Syrian theologians, in experiencing the divine rather than merely thinking and talking about it," 105 this experience is precisely obtained not only to the benefit of the soul but also of the body. In my opinion, this is one of the real reasons why "Iamblichus does not discuss about the specifics of theurgic ritual" that are to be found in Dionysian theurgy. ${ }^{106}$

Something needs to be said about the understanding of the cosmos as ekklésia,

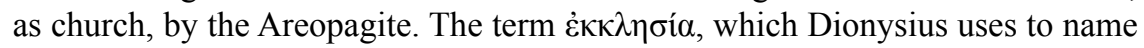
his treatise on the Ecclesiastical Hierarchy, ${ }^{107}$ where most of his account on theurgy is to be found, reflects one of the divine names he treats in his homonymous treatise, in predicating God. Florovsky puts it nicely:

God is the end of everything, for everything exists for his sake and receives from him its beauty; that is its proportion and measure. Following Plato (and Proclus) Dionysius produces $\kappa \alpha \dot{\lambda} \lambda \sigma \varsigma$ from $\kappa \alpha \lambda o \tilde{v} v$, to 'call, summon,' and repeats the Platonic idea of beauty as the object of attraction. It is precisely beauty which kindles love. (. . .) The beginning of every existence and order lies in this supreme beauty, for a single beauty attracts, unifies, and coordinates everything. Hence, all connections, all similarity, and all agreement in objective reality. Hence, measure and movement, heterogeneity and simplicity. Being above any division or multitude, God brings everything to himself as a higher, longed-for-beauty and blessing. ${ }^{108}$ 
Florovsky's illustration helps us to see clearly the motive and the aim of the Dionysian ecclesiastical hierarchy. The latter is not about a noetic, intellectual reconstruction, or even replacement, of the cosmos and natural reality. Precisely, as Florovsky clarifies it, the very constitution of the natural cosmos, the objectivity in it, which stems from the possibility to discern all connections and similarities in the cosmos, depends on, and derives from, the attribute of God as beauty

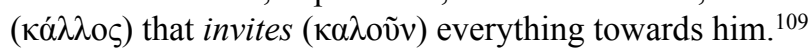

So for Dionysius there is nothing like contradiction, opposition, contrast, or conflict between the natural world and the ecclesiastical hierarchy. Precisely, the real, objective being of the cosmos is revealed as ekklessia and the hierarchy emerges and is shaped on the grounds of this divine call. If that is the case, then there by no means appears any need to ponder on whether Dionysian theurgy is cosmocentric or anthropocentric. Although not explicitly stated, but evidently, the Areopagite's theurgy is Christocentric. ${ }^{110}$ As St Maximus the Confessor asserted later, man is the mediator between God and His cosmos. The aim of Dionysian hierarchy is to emphasise this role of the human being, which after the Fall needed Christ, the new Adam, in order to re-establish her in her initial position as mediator between God and his creation. This I take to be the real meaning of what Arthur Hilary Armstrong had in mind in saying that "there is here a new and radical sort of religious anthropocentricism, which may have had far-reaching consequences." 111

If that is the case, there emerge serious doubts about the accuracy of Shaw's claim that "(. . .) Dionysius placed them [the sacred symbols that Origen had recognized within the natural world] solely within the Church, and by shifting the context of theurgy from the natural to an ecclesiastic world he necessarily changed the very nature of the 'divine work'."112 Obviously, and in the light of Florovsky's passage above, the distinction between natural and ecclesiastic world in Dionysius is simply a false one. Neither the ekklessia is something other than the natural cosmos, nor the very nature of the "divine work" is anything other than God's providential, creative, sustaining, salvific, and deifying activity of the very cosmos. Consequently, the Areopagite does not implement any shifting of the context of theurgy from "the natural to an ecclesiastic world," which would necessarily imply a change in the very nature of the "divine work." 113 In his mind there is no distinction between natural and ecclesiastical cosmos: it is one and the very same cosmos. ${ }^{114}$

\section{Conclusions}

The unbiased reader of Dionysius who chooses to interpret his works by focusing on the tradition the Areopagite adheres to rather than on the "external" similarities emerging from the vocabulary and the terminological apparatus of Neoplatonism he makes use of, would be alerted to the misunderstandings that bind part of the literature. At the heart of such miscomprehensions of the Dionysian universe one finds the identification of Dionysian theurgy with the long Neoplatonic and Hellenic-broadly speaking-theurgic tradition and practice. ${ }^{115}$ To see 
Dionysian theurgy through Neoplatonic lenses amounts to considering $\theta$ covp $\gamma^{\prime} \alpha$ as a mere human activity, even if performed by men who have been purified according to the Neoplatonic rites appropriate for that matter. ${ }^{116}$ This would not be far away from taking theurgy according to the Areopagite as another "special branch of magic," to borrow the provocative words of Eric Robertson Dodds. ${ }^{117}$ If one accepted the above, one would necessarily be bound to identify theurgy with hierurgy, thus dangerously circumventing the fundamental Dionysian distinction between the two.

What has been argued throughout this chapter is that the Areopagite does not employ $\theta \varepsilon o v \rho \gamma i \alpha$ on Neoplatonic or other pagan mystical grounds. The content of the term is radically transformed by him in order to depict a reality unconceivable within Neoplatonism. As Stock puts it, "Dionysius uses both the Christian and the Neoplatonic traditions to create a new concept of theourgia in which the aesthetic value of the ritual plays an important philosophical role." 118 In other words, it is possible that a term receives a new content, deriving from the specifics of a radically different world view. For Dionysius is clear that the world does neither derive emanatively from the One nor expand downwards through a manifold of divine entities with an active role in the formation of the cosmos, as it is the case with the Proclean interpretation of the cosmology of the Timaeus. ${ }^{119}$ One might rightly object that the principle of creatio ex nihilo is not found in the Corpus; yet, the Dionysian setting is rather a creationist one. ${ }^{120}$ What is more, the cosmos does not owe its being to a multiplicity of Gods but to the one God who theurgises, creates entirely and exclusively without the aid of intermediate deities. ${ }^{121}$

The Areopagite is not a theurgist in the sense the term receives within Iamblichean Neoplatonic theurgy. For him, theurgy is all the rituals of the Christian tradition, the Sacraments, the most significant being the liturgy ( $\sigma 00 \alpha \xi 1 \zeta)$, which stands in remembrance ( $\dot{\alpha} v \alpha \dot{\alpha} \mu v \eta \sigma ı)$ ) of the earthly acts of Christ. The performance of the rituals, as Dionysius explains, is an act of hierurgy enacted by the hierarch and/or the priests (iepovproí). The Areopagite is very careful to never call the reception - and further transmission to the plèroma of the Church - of the sacraments theurgiai, but hierurgiai. Thus, theurgy is not a human activity but it is the divine activity received by the humans, and this reception is precisely an act of hierurgy. Therefore, hierurgy could not be taken as a term alternative to theurgy, as is the case in Iamblichus' theurgic account. The Areopagite should be credited with the novel distinction between the two: divine activity is to be hymned as theurgy, whereas human activity, either within the sacraments, or as participation in divinity through prayer, is to be praised as hierurgy. Moreover, Dionysius should be seen as a theurgist "by grace" on the grounds of synergy between God and man, and in the perspective of deification, which springs from God's Incarnation, Passion, Death, and Resurrection.

The major Dionysian contribution that derives as a corollary of his notion of theurgy is cosmological. It is about the enrichment of our understanding of the constitution of the cosmos. For him the cosmos is not dropped and abandoned in being, as Heidegger thought, but rather responding to a klessis that is both a renewal of it and the revelation of its origin and destination. The Dionysian 
universe, and the natural cosmos indeed, is a dynamic universe in movement towards an infinite reality that is theurgically established and constantly fulfilled. Thus, nature and all material and natural symbols are not merely synthēmata to be intellectually conceived in order to facilitate a certain change of the psychological status; they are imprints of an ongoing ontological innovation and enrichment of the entire creation, of all particulars and universals. Dionysian theurgy aims precisely at the salvation of man and the entire creation. As such, it has "no parallel in the theurgy of Proclus or Late Neoplatonism in general." 122 This novelty certainly goes far beyond the (humanly governed) institutional capacities of any Church. ${ }^{123}$ Besides, one should not forget that it was precisely the "institutional church" of those times that rejected and crucified Him Who is the source of the Church, the source of Dionysian theurgy.

\section{Notes}

1 Parts of this chapter were initially prepared for the International Workshop Dionysius Areopagita Christianus: Approaches to the Reception and Reconstruction of the Christian "Tradition" in the Areopagitic Writings, at the University of Athens (February 2017). An improved and enriched version was presented at the 15th Annual Conference of the International Society for Neoplatonic Studies, in Olomouc, Czech Republic (June 2017). I wish to thank the organisers of the Workshop in Athens, Georgios Arabatzis and Dimitrios Pallis, for the invitation. My gratitude extends in particular to John Finamore and the ISNS Conference Committee for accepting the final paper and offering a grant for its presentation. Lloyd P. Gerson commented on an earlier version of the chapter. With Dylan Burns and Crystal Addey we had fruitful discussions during the ISNS Conference. Dimitrios A. Vasilakis and Christian Bull offered me several valuable insights. The series editors, Mark Edwards and Lewis Ayres, supplied me with substantial comments. I am grateful to all of them. Finally, I wish to particularly express my gratitude to my co-editors and supervisors of my doctoral dissertation, Torstein Theodor Tollefsen and Eyjólfur Kjalar Emilsson, for their encouragement, continuous inspireful support and friendship, and to Lars Fredrik Janby for our intensive collaboration.

2 Dionysius, EH I.1; PG 3: 372a.

3 Cf. Vanneste 1959; Saffrey 1966; Saffrey 1982; Sorabji 1990; Shaw 1999; Dillon 2014. See also the famous dictum of Anders Nygren (Agape and Eros) who built upon Martin Luther and said about the Areopagite that "the fundamental Neoplatonism is but scantily covered with an exceedingly thin Christian veneer." For this quotation from Nygren and other interesting remarks on his view of Dionysius as "platonising" rather than "christianising," see Golitzin 1999: 131-133.

4 Indeed, the literature is growing. I simply refer, in a comparative mode, to the overall placement of Dionysian studies with regards to the sum of studies on Neoplatonism.

5 For instance, Dillon 2014: 111-112. For a collection of central studies on this issue, see Burns 2004: 111, n. 1. To my knowledge, the most recent work focusing on theurgy in the pagan world is the detailed study of Crystal Addey Divination and Theurgy in Neoplatonism: Oracles of the Gods, cf. Addey 2014, which contains a rich bibliography on Neoplatonic theurgy.

6 Burns holds the view that "it is only by examining Proclus' practice beyond his treatises, in their sociohistorical context, that Pseudo-Dionysius' reasons for changing the Iamblicho-Proclean theurgic model become clear," cf. Burns 2004: 113.

7 Sorabji 1990: 11-12.

8 This reflects Shaw's conclusive argument, in Shaw 1999: 598-599. 
9 Andrew Louth has made some very clear points with regard to Dionysius' originality in relation to Neoplatonism, in Louth 1989: 84-87. See also Florovsky 1987: 204-229 and Golitzin 1999. Vasilakis espouses this view in his chapter On the Meaning of Hierarchy in Dionysius the Areopagite, in the present volume.

10 Dionysius, Ep. 9.1, Heil and Ritter 1991: 198.3-5; PG 3: 1108a. This is nothing other than the Last Supper offered by Christ to His disciples, shortly before the betrayal and the Passion.

11 Dionysius, Ep. 4, Heil and Ritter 1991: 161.5-10; PG 3: 1072c.

12 This has been noticed by the Dionysian scholarship more than a century ago, with the studies of Hugo Koch and Josef Stiglmayr, cf. Perczel 2000: 491. See also, Louth 1986: 432; Louth 1989: 81; Golitzin 1999: 133-134, and Dillon 2014: 112.

13 John Rist has something interesting to say about how Dionysius uses Neoplatonic language in a different conceptual orientation, in Rist 2010: 245-246.

14 Vladimir Lossky moves even further, when he notes that "we must not imagine that Christian and pagans lived in water-tight compartments, especially in Alexandria where both participated in the same culture, in the same intellectual life," cf. Lossky 1983: 67. Lossky regards the community of language and the common methodology as two aspects of the natural kinship of the same cultural tradition shared by both the pagan and Christian contemplatives of Alexandria (ibid.: 68). So, by speaking of "different orientation of the use of a common language," I refer to what Lossky points out as "different religious frameworks of the same thems of Hellenistic spirituality," (cf. ibid.: 67).

15 Cf. ibid.: 121-122.

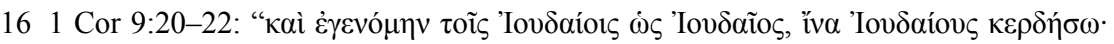

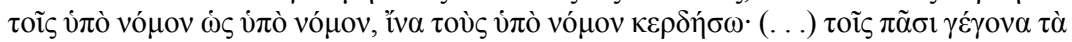

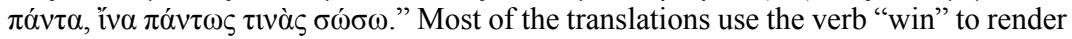

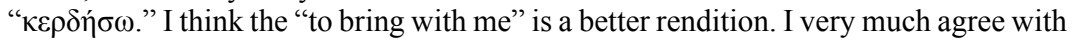
Dimitrios A. Vasilakis, who comments, in this respect of the relation of the unknown author of the $C D$ with St Paul that "historical fiction is different to spiritual indebtedness." Cf. Vasilakis' chapter in this volume, n. 44.

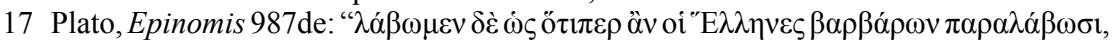

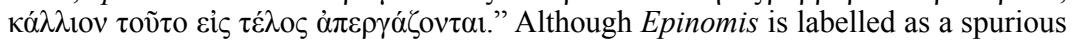
work (Diogenes Laertius (Plato, III.37, and 46) registers that some people say that the author of the Epinomis was Plato's disciple Philippus of Opus). In any case, I find this passage perfectly illustrating Plato's own method and practice.

18 I personally prefer such an interpretative possibility for a productive synthesis in Dionysius; it goes beyond a rather superficial view and "comparison" of the Christian and Platonist tradition in terms of superiority of the former, as asserted in Wear and Dillon 2007: 12. Besides, this attitude is not exclusively Dionysian. It is already present in the thought and the works of St Basil the Great.

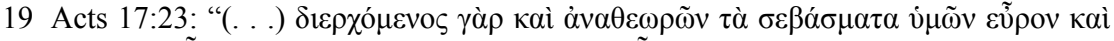

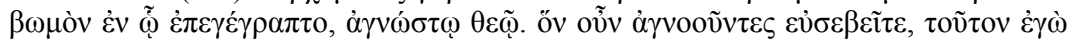

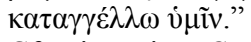

20 Cf. Dionysius, CH IV.1, Heil and Ritter 1991: 20.9-11; PG 3: 177c. Although one might have wished to have a more explicit statement by Dionysius on the creatio ex nihilo of the cosmos, I think it is safe to admit that, even in an implicit manner, the Areopagite adheres to the creation of the cosmos by God out of nothing. Louth (1989: 85), notes that Dionysius "never speaks of creation ex nihilo, even though by this time the idea of creation out of nothing had become the normal and accepted way in which Christians expressed their belief in creation." For the possibility of maintaining a creationist view within the phenomenally emanationist Neoplatonic setting in the Areopagite's works, see Damian 2011: 96-97. On the possibility of taking $\pi \alpha \rho \alpha \gamma \omega \gamma \eta$ in Dionysius as implying creation out of nothing, see Golitzin 2013: 105-113. For an inquiry into a Christian orthodox doctrine of 
creation in the Areopagite, see Tollefsen 2008: $113 \mathrm{ff}$. The reader would greatly benefit from Tollefsen's chapter on Proclus, Philoponus, and Maximus: The Paradigm of the World and Temporal Beginning, in this volume, where Tollefsen compares Neoplatonic and Christian doctrines of creation. Following his argument that "the classical Christian doctrine of creation reached its completion in major thinkers of the fourth century," it is plausible to claim, I think, that the Areopagite could but have adhered to this doctrine, as well. This claim could also be supported by Brown Dewhurst's chapter in the present, where she argues for fundamental divergences between Proclus and St Maximus the Confessor in their views on the origin of the cosmos. The given agreement of Dionysius with St Maximus on the existence of one Triune God who creates without the aid of intermediate deities would be enough to conclude that the Areopagite adheres to creation rather, than to emanation. See also, infra n. 121.

21 Rorem admits, though, that the similarities between Iamblichus and Dionysius do not necessarily mean that the Areopagite read De Mysteriis. Cf. Burns 2004: 112.

22 Louth 1986: 432.

23 Struck 2001: 25-26. One could, for instance, think of St Gregory of Nyssa, who in many regards has been much influential to Dionysius, cf. Golitzin 1999: 136 and Florovsky 1987: 213. But as the Lexicon Gregorianum shows, there is no use of the term $\theta \varepsilon o v \rho \gamma i$ í by Gregory. However the case may be, I would agree with Rorem's conclusion that "Dionysius' ritual theory must be understood 'in general (. . .) in the context of basically patristic precedents'." Cf. Struck 2001: 26.

24 Cf. Burns 2004: 121.

25 Dillon 1973: 29.

26 Rorem 1984.

27 Shaw 1999: 582. The tripartite division of mankind and souls is also present in preIamblichean traditions, such as Valentinians, Sethians and Hermetists. Dylan Burns has summed up the arguments of Rorem and Shaw about the aspects of Iamblichean theurgy that, according to them, are replicated by Dionysius, cf. Burns 2004: 112.

28 Note, for instance, the divergences between Proclus and Plotinus on the question of matter as badness, as it is specially treated in Emilsson's chapter Plotinus' Doctrine of Badness as Matter in Ennead I.8., in this volume.

29 See passage $\mathrm{T} 2$ below.

30 Burns has some useful notes about the tendency of comparing Dionysius with Iamblichus, and not Proclus, on theurgy, in Burns 2004: 113 and n. 9. It would also be fruitful to explore other possible reasons for a closer relation of Dionysius to Iamblichus rather than to Plotinus, in the perspective of what Chlup calls Iamblichean 'eastern' Neoplatonism, cf. Chlup 2012: 18, that flourished in the 4th century Syria.

31 Louth 1986: 434.

32 See, for instance, De Myst. III.11, 125.4-5; III.24-25, 157.12-14; III.27, 165.7-10; IV.8, 192.1-3; V.10, 210.11-12; X.3, 287.15-288.1; Clarke et al. 2003: 146-147, 178-179, 186-187, 214-216, 240-241, 346-347. See also Shaw 1999: 596, and Shaw 1995: 86-87. Crystal Addey notes that epitédeiotess in Iamblichus summons "the ritual, intellectual and ethical qualities which were considered to be essential for the theurgist to develop," and she argues that the term accounts for the difference

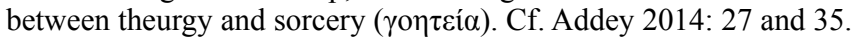

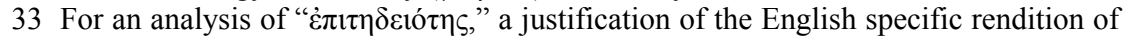
the term, and insights on "aptitude" in Late Antique and Early Christian thought, see Pavlos 2017a and 2017b.

34 Cf. Emilsson and Strange 2015: 28. See also Schroeder 2014, an excellent piece on the influence of Alexander to Plotinus; although it does not treat epitédeiotēs explicitly, the specific influence can be extracted as a corollary from Schroeder's analysis. 
35 I investigate this further in my doctoral dissertation, "The concept of Aptitude ('E $\left.\pi \imath \tau \eta \delta \varepsilon เ{ }^{\tau} \eta \varsigma\right)$ in Late Antique and Early Christian Thought," at the Department of Philosophy, University of Oslo. For sporadic but substantial remarks on epitédeiotess in the thought of St Maximus the Confessor, see Tollefsen 2008: $185 \mathrm{ff}$.

36 On epitēdeiotēs in a physical context, see Sambursky 1962: 104-109. For remarks on epitêdeiotês in Philoponus' cosmological account, see Tollefsen's chapter in this volume.

37 Plotinus, Enn. VI.4.11, 3-4; VI.4.15, 1-6; 12-13. Cf. Emilsson and Strange 2015: 26-28.

38 Rarely, however, Iamblichus employs the term as associated to an agent rather than a patient. Cf. Clarke et al. 2003: 217.

39 Sambursky 1962: 106.

40 Iamblichus, De Myst. III.11, 124.14-125.6; Clarke et al. 146-147.

41 I am basically commenting on the last sentence of passage T1, which I have added in Greek. It is however possible to discern the "normal" Plotinian influence on Iamblichus' understanding of epitédeiotēs, when Iamblichus refers to prayer. He asserts that prayer is effective in that it "enlarges very greatly our soul's receptivity to the gods, reveals to men the life of the gods, accustoms their eyes to the brightness of divine light, and gradually brings to perfection the capacity of our faculties for contact with the gods." Cf. Wear and Dillon 2007: 63. Here we have the original Plotinian motive of a certain (innate) potency that is supported "internally" - not through material items - by epitédeiotēs. This Iamblichean passage is interesting also because it illustrates the dynamic character of epitédeiotes that affects potency in two ways: it both leads it to actualisation and increases it.

42 Dionysius, Ep. 8.2, Heil and Ritter 1991: 180.12-16. Cf. Wear and Dillon 2007: 95. Interestingly, Iamblichus does not maintain the Plotinian picture that is apparently preserved by Dionysius when the latter asserts that there is an approximation with the divine not in spatial terms but according to the aptitude for receiving God. Plotinus originally illustrates this idea in Enn. VI.4.15.

43 Iamblichus, De Myst. V.23, 233.9-13; Clarke et al. 268-269.

44 Cf. Plotinus, Enn. II.9.

45 Dodds asserts that the term "theurgy" is not found anywhere in Plotinus' Enneads, cf. Coughlin 2006: 150. Louth (1986: 432) notes that, "Plotinus had no time for theurgy: the world $\theta \varepsilon o v \rho \gamma i \alpha$ is not used in the Enneads, he uses the older, derogatory word,

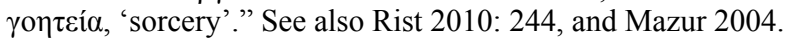

46 Cf. Clarke et al. 2003: 269. My understanding is that Iamblichus qualifies the aforementioned material objects as sacred, perfect and divine already before, and apart from, their specific theurgic composition and transformation into a receptacle.

47 Shaw 1999: 596.

48 Iamblichus, De Myst. V.18-19, 225.1-4; Clarke et al. 2003: 256-259.

49 The integration of theurgy in Proclean Neoplatonism is perhaps the most fruitful evidence to this. Cf. Van den Berg 2014: 261.

50 Indeed, it would be somewhat oversimplifying to pose a radical distinction

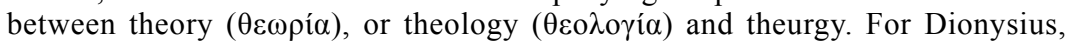
who had seen theourgia as the consummation of theologia, this would have been impossible. This Iamblichean passage confirms Zeke Mazur, who argues that "theōria and theurgia are ambiguous categories that admit of some overlap." Thus, contemplation cannot be understood as simple intellection, just as theurgy does not merely designate external or material ritual practices, cf. Coughlin 2006: 151. At the same time, Iamblichus is well aware of the distinct roles of theology, theurgy and philosophy, when he promises that he shall provide explanations to Porphyry's attacks in a manner proper to the respective question, cf. Coughlin 2006: 151. 
51 Iamblichus, De Myst. VI.6, 246.12-247.2; Clarke et al. 2003: 286-287. I add the Greek text here because it bears similarities with a significant Dionysian extract we

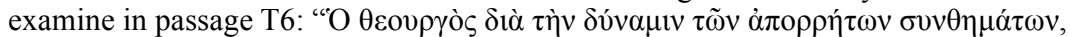

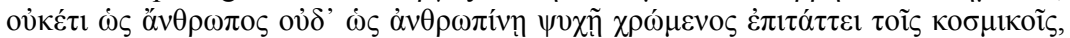

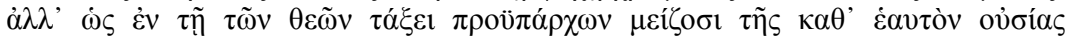

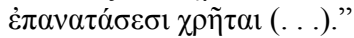

52 Needless to mention the enthusiasm I experienced when in my first reading of De Mysteriis I realised how much of pagan reality is preserved in the series of comics "Astérix," by René Goscinny and Albert Uderzo. There, the equivalent to the Colophonian oracle's water mentioned by Iamblichus in De Mysteriis, is the magic broth made by the druid with an arcane recipe that only he knows.

53 Two remarks here. The first is that such a being, perfect God and perfectly man, would sound to Iamblichean ears at least as strange as it would sound to Plotinus' the inclusion and identification of the absolute Universal, the One, to an absolute particular, a man, and this made of without the aid of any mystical ascent. Secondly, the reader should not think that I use - arbitrarily, one might say - the Council of Chalcedon as a means to heal what has been admitted by Georges Florovsky as "a certain vagueness of Dionysius' christological ideas," cf. Florovsky 1987: 225. Rather, I do wish to stress in this way the permanence of theurgic identity in Areopagite's theourgos against the temporality of theurgic properties in Iamblichus'.

54 Dionysius, EH III, Heil and Ritter 1991: 79.1-94.22. Cf. Louth 1989: 60.

55 Ibid.

56 Louth 1986: 434.

57 On the relation of this initial status of sacraments to the later tradition of the Church, see Louth 1989: 57-58.

58 Indicatively, see Florovsky 1987: 225.

59 Cf. for instance, Grillmeier and Hainthaler 2013: 311-342.

60 Dionysius, EH I.1, Heil and Ritter 1991: 63.12-64.4; PG 3: 372a; Parker 1897: 168.

61 Dionysian theology stems from the Scriptural truth that is tirelessly repeated throughout the Corpus. The Areopagite acknowledges one Triune God. In $E H$ he affirms the triadic in unity blessedness of the beyond all Godhead as the singular cause of beings, the source of life, the principle of hierarchy and the essence of

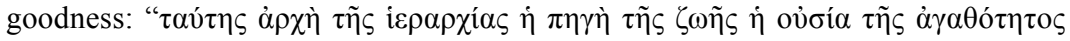

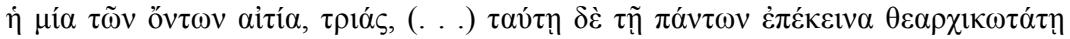

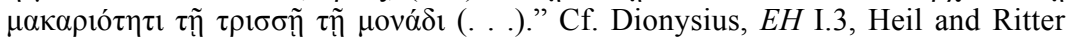
1991: 66.6-9; PG 3: 373cd.

62 Dionysius, Ep. 4, Heil and Ritter 1991: 161.5-10; PG 3: 1072bc; Parker 1897: 95:

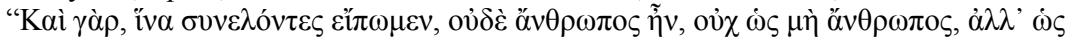

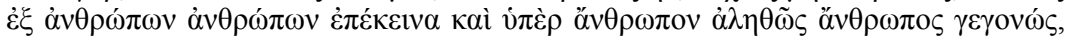

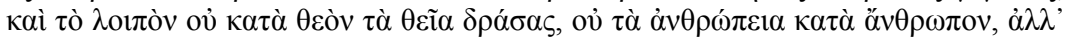

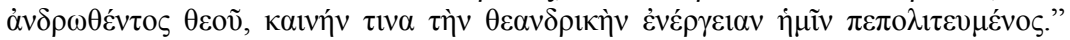
Note the dialectics of affirmations and negations with regard to the nature(s) of Christ, in this passage: they demonstrate an understanding of "theurgist" by the Areopagite radically contrasting the Iamblichean theurgist who "commands cosmic entities no longer as a human being or employing a human soul (. . .)", in passage T4.

63 Saffrey 1966: 98.

64 Dionysius, $C H$ IV, Heil and Ritter 1991: 22.25-23.5; PG 3: 181b; Parker 1897: 158.

65 Dionysius, EH III, $\theta \varepsilon \omega p i ́ \alpha$ 5, Heil and Ritter 1991: 84.18-21; PG 3: 432b. I use the translation of the passage made by Struck, in Struck 2001: 31. Notably, the term $\tau \varepsilon \lambda \varepsilon \sigma 10 v \rho \gamma i \alpha$ is employed by Iamblichus in several places in the De Mysteriis.

66 Louth 1986: 434. Louth's claim has been given a solid grounding after the work on Dionysian Christology by Grillmeier and Hainthaler 2013.

67 Florovsky 1987: 211. I am very grateful to fr. Johannes Johansen, rector of the Norwegian Orthodox Church of St Nicholas in Oslo and Christ's Transfiguration Parish 
in Rogaland, and to Torleif Thomas Grønnestad, for granting me access to the Stavanger Orthodox Library, whereby I borrowed a copy of the otherwise hardly accessible Collected Works of fr. Georges Florovsky.

68 I found the analysis of this subject in Emilsson 1999 very illuminating.

69 For the time being, I am happy to leave this claim in its present form without further justification.

70 See respective lemmas, in Nasta 2013: 3.

71 Florovsky 1987: 211.

72 See relevant remarks on "synergy" in Vasilakis' chapter in this volume, nn. 45 and 96.

73 Florovsky 1987: 216.

74 Ibid.

75 Dionysius, DN XI.5, Suchla 1990: 221.5-10; PG 3: 953a.

76 See also the section on Theourgia - Hierourgia (Chapter 7), in Wear and Dillon 2007: 99-115.

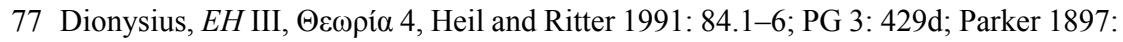
202.

78 Dionysius, Ep. 9.1, Heil and Ritter 1991: 198.3-5; PG 3: 1108a.

79 Gontikakis 1984: 61-62.

80 Ibid. A modern "theurgist" would also claim the same about the revival of Iamblichean theurgy nowadays. The difference lies on what exactly is acted.

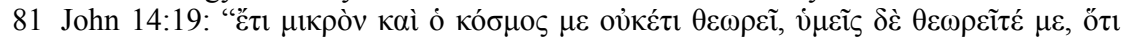

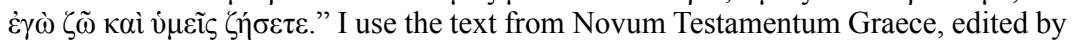
Nestle-Aland.

82 Louth 1986: 435.

83 I would partially agree with Burns, who argues that "when he [Dionysius] argues that 'theurgy is the consummation of theology,' he refers to a systems of ritual liturgics in which the priest not only needs to be saved through theurgic symbols, but needs to save others by using them properly, as prescribed." The terms "save others" and "using" that Burns employs, assign the Dionysian priest with a task that I do not think it is prescribed by the Areopagite. Cf. Burns 2004: 122 and n. 49.

84 Cf. Russell 2006: 258.

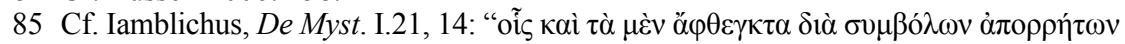

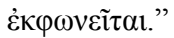

86 Wear and Dillon 2007: 102.

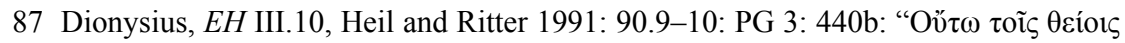

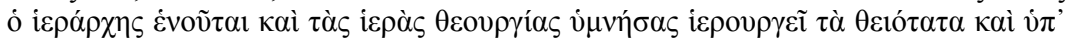

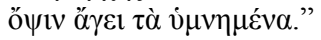

88 John Finamore notes further that, for Iamblichus, "the largest segment of humanity is held down by nature, is subject to fate, and never rises. Other human beings can and do make progress through theurgical ascent." Cf. Finamore 2014: 289. By "kata symbebēkos" I refer to the minority of humans identified above by Finamore.

89 Louth 1986: 434.

90 Cf. the excellent illustration of this cosmic freedom, in Florovsky 1987: 218.

91 One may reasonably think that, in such a cosmic setting, the Neoplatonic generalisation of Stoic sympatheia, that applies to the entire cosmos and opens room to Iamblichean theurgy, needs a radical revision.

92 Cf. Ivanovic 2017: 150.

93 It is a central conviction of the Areopagite, shared by St Maximus the Confessor as well, that synergy between God and man is the foundation for deification of the latter, cf. Ivanovic 2019: 210.

94 Shaw 1999: 589.

95 Ibid.: $587-590$.

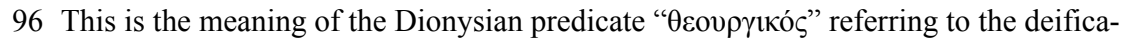
tion of the human being. See also Wear and Dillon 2007: 102. 
97 This does not contradict my previous claim that for Dionysius the only theurgist is Christ. For deification of the human being amounts to likeness to Christ in His complete Glory (as far as possible), a glimpse of which was offered to few disciples, the day of Transfiguration. And so long human beings become Christlike they become theurgists.

98 Shaw 1999: 595.

99 Ibid.: 573.

100 I very much suspect that apologetics are to be found on both sides of the river, both on the Neoplatonist and the Christian shore. In general, the apologetics, though often under attack, are neither bad people nor inaccurate with regard to the evidence. Socrates, for instance, was such a person, as Plato reminds us in his Apology of Socrates.

101 Shaw 1999: 595-596.

102 In the tendency of the literature to bring together Dionysius and Proclus (and Iamblichus) on theurgy, Christ is regarded as a Dionysian symbol, cf. Burns 2004: 125. But this raises the question whether Christ is a symbol, and, if yes, of what. For the Areopagite Christ is a being, perfect God and man. A symbol refers by definition to something beyond itself. But is there anything beyond, or apart from, Christ to be symbolised by Him? I think Dionysius' answer, as it comes out from his Corpus, is no. If that is the case, then Christ could be taken as a symbol only on the basis of being a symbol of Himself. But, then, are we not far way from Neoplatonism? Perhaps the reasons that prompt one to think of Christ as a symbol in a Neoplatonic manner, could be understood on the basis of the Dionysian method of paraphrasing respective passages from Proclus' Platonic Theology, in which the role of Jesus is analogous to that of Plato. But, again, these analogies hide fundamental divergences that lead me to the view I presented above. István Perczel's analysis is very fruitful and I shall only borrow one point to support my claim: "In other words, he [Jesus] is not only the principal Revelator as is Plato in Proclus' system, but also the Revealed and the Revelation itself." Cf. Perczel 2000: 501-502. Perczel concludes his comparative reading by noting that "instead of [Jesus] being a messenger of the higher beings [as Plato is], he [Jesus] is their principle", in ibid.

103 Shaw 1999: 595.

104 One may check the instances where the author of the $C D$ employs the term $\sigma \tilde{\omega} \mu \alpha$. But what I find sufficiently arguing for the Dionysian anticipation of the body's inclusion in deification - which also implies resurrection of the dead - is the eschatological passage from the $D N$ that connects deification with Christ's Transfiguration, in $D N$ I.4, Suchla 1990: 114.7-115.5; PG 3: 592c.

105 Shaw 1999: 595.

106 Ibid.: 596.

107 See n. 78 in Vasilakis' chapter in this volume, for details about the disputed label of the $E H$ treatise.

108 Florovsky 1987: 217.

109 See also Vasilakis' chapter in this volume and especially n. 24.

110 There is no passage in the $C D$ where Dionysius employs theurgy dissociated from Christ. Cf. Burns 2004: 125 and n. 66.

111 Armstrong 1973: 11.

112 Shaw 1999: 598.

113 Cf. Burns 2004: 127, who builds upon Shaw. The latter has a very interesting reference to St Maximus' the Confessor's Mystagogia, a work that, indeed, can be seen as a commentary on Dionysius' Ecclesiastical Hierarchy. There Maximus refers to the church as an "image of the sensible world" and he says that "the world can be thought of as a church," cf. Shaw 1999: 598, n. 105. Although I could not supply myself with 
the translation of Mystagogia Shaw had at his disposal, I believe the renditions above, apart from being selective, do not perfectly reflect the Greek text, where Maximus says precisely the following (bold phrases are made intentionally to correspond to

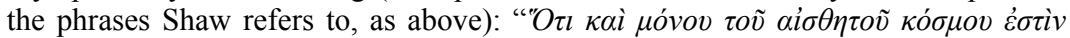

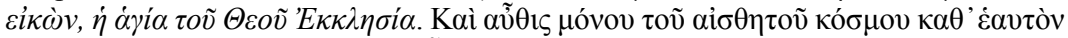

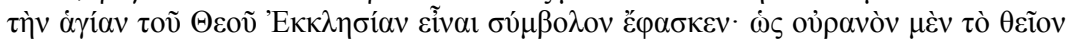

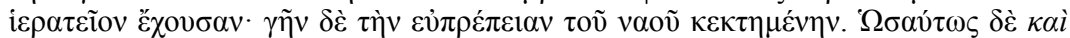

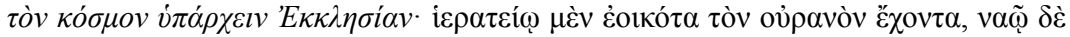

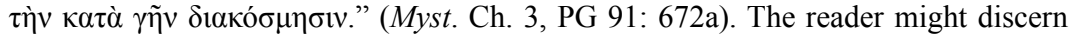
certain concealments that allow Shaw to conclude, by means of a selective reading of this Maximian passage that "the world as church or temple is perfectly consistent with the principles of Iamblichean theurgy, so long as our church is not the only church." I fully align myself with Shaw, however, in his objection about the church; I agree with him, since for both Dionysius and Maximus, the church is definitely not the one he rightly feels allergic about.

114 The epistemic implications of this identification are enormous, but this would need a separate study.

115 For instance, Shaw's introductory wonder, in Shaw 1999, is "why are Christian theologians reluctant to admit that Dionysius was a theurgist." By "theurgist" Shaw refers to the Iamblichean definition of a theurgist as a man who performs theurgic rituals.

116 Iamblichus, De Myst. V.18-19, 225.1-4; Clarke et al. 2003: 256-259.

117 Dodds 1963: 283. On the origins and the meaning of the term " $\mu \alpha \gamma \varepsilon i ́ \alpha$," see Bull 2018: 398-404. Bull builds on the definition of "religion" as "an institution consisting of culturally patterned interaction with culturally postulated superhuman beings," by Melford Spiro, and provides the following definition of "magic": "then magic should be considered a subgroup of religion, since it consists of a specific form of interaction with the culturally postulated beings. If religion is 'institution', then magic is specific rituals performed within or - perhaps more commonly - on the fringes of said institution." I do not mean to say that Iamblichus considers theurgy as magic. He is quite

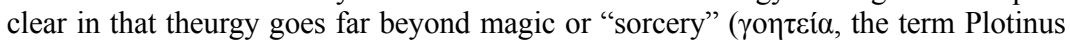
uses in his Enneads), the latter relying on sympathies within the material world; for him, theurgy requires the involvement of the divine will of gods. I simply mean that, from a Christian point of view, Iamblichean theurgy is about magic so long as it does not acknowledge a single divine activity of one God; a singular activity that is, the more, not dependent on an evocation of a manifold of deities. For the relationship between theurgy, magic and religious practices in Late Antiquity, see Addey 2014: 32-38.

118 Stock 2013: 14.

119 Unlike the Timaeus, and the entire Neoplatonic tradition, Dionysius has a creator god who brings the universe into being theurgically, without the aid of subordinate gods, cf. Lossky 1983: 124-125.

120 See nn. 20 and 121.

121 I fully agree with István Perczel who argues that in "Dionysius' Christian Platonist system (...) the creating activity is not distributed among different divine entities or hypostases like in Proclus, but is attributed to the highest and universal cause of all things. Proclus' Demiurge is a subordinate deity occupying a rather modest rank in

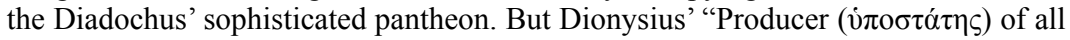
things" is the supreme Godhead (. . .)." Cf. Perczel 2000: 494.

122 I think here Burns is absolutely right. Cf. Burns 2004: 127.

123 I very much agree with Shaw's criticism of the "institutional church," cf. Shaw 1999: 599. 


\section{Panagiotis G. Pavlos}

\section{Bibliography}

\section{Primary sources}

\section{a. Editions}

Clarke, Emma C., John M. Dillon and Jackson P. Hershbell (eds. and trans.) (2003). Iamblichus, De Mysteriis. Atlanta, GA: Society of Biblical Literature.

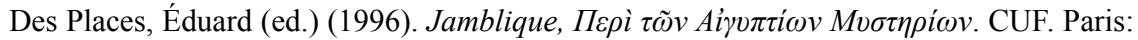
Les Belles Lettres.

Dillon, John M. (ed.) (1973). Iamblichi Chalcidensis In Platonis dialogos commentariorum fragmenta. Leiden: Brill.

Heil, Günter and Adolf M. Ritter (eds.) (1991). Corpus Dionysiacum II. Pseudo-Dionysius Areopagita, De Coelesti hierarchia, De ecclesiastica hierarchia, De mystica theologia, Epistulae. Berlin/Boston: De Gruyter.

Henry, Paul and Hans-Rudolf Schwyzer (eds.) (1964-1982). Plotini Opera. Scriptorum Classicorum Bobliotheca Oxoniensis. 3 Vols. Oxford: Clarendon Press.

Hicks, Robert Drew (ed. and trans.) (1972). Diogenes Laertius, Lives of Eminent Philosophers. Books 1-5. LCL. Vol 184. Cambridge, MA: Harvard University Press.

Migne, Jacques-Paul (ed.) (1857). Dionysius Areopagita. PG. Vols. 3-4. Paris: Imprimerie Catholique.

Nasta, Michai (ed.) (1993). Thesaurus Pseudo-Dionysii Areopagitae. Corpus Christianorum Thesaurus Patrum Graecorum. Turnhout: Brepols.

Suchla, Beate Regina (ed.) (1990). Corpus Dionysiacum I. Pseudo-Dionysius Areopagita, De Divinis Nominibus. PTS. Vol. 33. Berlin/New York: De Gruyter.

\section{b. Translations}

Emilsson, Eyjólfur Kjalar and Steven Keith Strange (eds. and trans.) (2015). Plotinus, Ennead VI.4 and VI.5: On the Presence of Being, One and the Same, Everywhere as a Whole. Las Vegas/Zurich/Athens: Parmenides Publishing.

Parker, John (trans.) (1897). Dionysius the Areopagite, Works. Oxford: James Parker and Co.

\section{Scholarly literature}

Addey, Crystal (2014). Divination and Theurgy in Neoplatonism: Oracles of the Gods. London/New York: Routledge.

Armstrong, Arthur Hilary (1973). "Man in the Cosmos: A Study of Some Differences between Pagan Neoplatonism and Christianity." In Romanitas et Christianitas, ed. Willem den Boer, Pieter G. Van der Nat, Christiaan Marie Jan Sicking, and Jacobus C.M. Van Winden, 5-14. London: North Holland.

Bull, Christian H. (2018). The Tradition of Hermes Trismegistus: The Egyptian Priestly Figure as a Teacher of Hellenized Wisdom. Religions in the Graeco-Roman World. Vol. 186. Leiden/Boston: Brill.

Burns, Dylan (2004). "Proclus and the Theurgic Liturgy of Pseudo-Dionysius." Dionysius 22: 111-132.

Chlup, Radek (2012). Proclus: An Introduction. Cambridge: Cambridge University Press. 
Coughlin, Rebecca (2006). "Theurgy, Prayer, Participation, and Divinization in Dionysius the Areopagite." Dionysius 24: 149-174.

Damian, Theodor (2011). "The Doctrine of Creation in Pseudo-Dionysius Areopagite's Theology." Annals of the Academy of Romanian Scientists: Series on Philosophy, Psychology, Theology and Journalism 3.1-2: 89-112.

Dillon, John M. (2014). “Dionysius the Areopagite.” In Interpreting Proclus: From Antiquity to the Renaissance, ed. Stephen Gersh, 111-124. Cambridge: Cambridge University Press.

Dodds, Eric R. (1963). The Greeks and the Irrational. Berkeley: University of California Press.

Emilsson, Eyjólfur Kjalar (1999). "Remarks on the Relation between the One and the Intellect in Plotinus." In Traditions of Platonism: Essays in Honour of John Dillon, ed. John J. Cleary, 271-290. Aldershot: Ashgate.

Finamore, John (2014). "Iamblichus on Soul." In The Routledge Handbook of Neoplatonism, ed. Pauliina Remes and Svetla Slaveva-Griffin, 280-292. London/New York: Routledge.

Florovsky, Georges (1987). The Byzantine Ascetic and Spiritual Fathers. Vol. 10 in The Collected Works of Georges Florovsky, ed. Richard S. Haugh. Vaduz: Büchervertriebsanstalt.

Golitzin, Alexander (1999). “'A Contemplative and a Liturgist': Father Georges Florovsky on the Corpus Dionysiacum.” St Vladimir's Theological Quarterly 43: 131-161.

- (2013). Mystagogy: A Monastic Reading of Dionysius Areopagita. 1st edition 1994. Cistercian Studies Series 250. Collegeville: Cistercian Publication.

Gontikakis, Vasileios (1984). Hymn of Entry, Liturgy and Life in the Orthodox Church. New York: St. Vladimir's Seminary Press.

Grillmeier, Alois and Theresia Hainthaler (eds.) (2013). Christ in Christian Tradition. Vol. 2, Part 3. Oxford: Oxford University Press.

Ivanovic, Filip (2017). "Union with and Likeness to God: Deification According to Dionysius the Areopagite." In Visions of God and Ideas on Deification in Patristic Thought, ed. Mark Edwards and Elena Ene D. Vasilescu, 118-157. London/New York: Routledge.

(2019). Desiring the Beautiful: The Erotic-Aesthetic Dimension of Deification in Dionysius the Areopagite and Maximus the Confessor. Washington, DC: The Catholic University of America Press.

Lossky, Vladimir (1983). The Vision of God. Crestwood, NY: St. Vladimir's Seminary Press.

Louth, Andrew (1986). "Pagan Theurgy and Christian Sacramentalism in Denys the Areopagite." The Journal of Theological Studies, New Series 37.2: 432-438.

(1989). Denys the Areopagite. London/New York: Continuum.

Mazur, Zeke (2004). "Unio Magica: Part II: Plotinus, Theurgy and the Question of Ritual." Dionysius 22: 29-55.

Nasta, Michai (ed.) (1993). Thesaurus Pseudo-Dionysii Areopagitae. Corpus Christianorum Thesaurus Patrum Graecorum. Turnhout: Brepols.

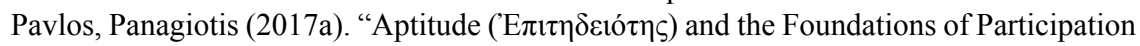
in the Philosophy of Dionysius the Areopagite." Studia Patristica 96: 377-396.

- (2017b). "Christian Insights into Plotinus' Metaphysics and His Concept of Apti-

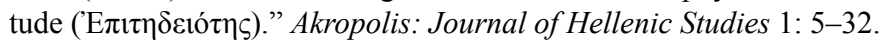

Perczel, István (2000). "Pseudo-Dionysius and the Platonic Theology: A Preliminary Study." In Proclus et la Théologie Platonicienne. Actes du Colloque International de Louvain (13-16 Mai 1998). En l'honneur de H.-D. Saffrey et L.G. Westerink, 
ed. Alain-Philippe Segonds and Carlos Steel with the Help of Concetta Luna and A. F. Mettraux, 425-443. Leuven/Paris: Leuven University Press/Les Belles Lettres.

Rist, John M. (2010). Plotinus: The Road to Reality. 1st edition 1967. Cambridge: Cambridge University Press.

Rorem, Paul (1984). Biblical and Liturgical Symbols within the Pseudo-Dionysian Synthesis. Studies and Texts 71. Toronto: Pontifical Institute of Medieval Studies.

Russell, Norman (2006). The Doctrine of Deification in the Greek Patristic Tradition. Oxford: Oxford University Press.

Saffrey, Henri-Dominique (1966). "Un lieu objectif entre le Pseudo-Denys et Proclus." In SP IX, Texte und Untersuchungen zur Geschichte der Altchristlichen Literatur, Bd. 92-94, ed. Frank Leslie Cross. Berlin: Akademie-Vorlag.

(1982). "New Objective Links between the Pseudo-Dionysius and Proclus." In Neoplatonism and Christian Thought, ed. Dominic O'Meara, 64-74. Albany: State University of New York Press.

Sambursky, Samuel (1962). The Physical World of Late Antiquity. London: Routledge/ Kegan Paul.

Schroeder, Frederic M. (2014). "From Alexander of Aphrodisias to Plotinus." In The Routledge Handbook of Neoplatonism, ed. Pauliina Remes and Svetla Slaveva-Griffin, 293309. London/New York: Routledge.

Shaw, Gregory (1995). Theurgy and the Soul: The Neoplatonism of Iamblichus. University Park, PA: The Pennsylvania State University Press.

_ (1999). "Neoplatonic Theurgy and Dionysius the Areopagite." Journal of Early Christian Studies 7.4: 537-599.

Sorabji, Richard (ed.) (1990). Aristotle Transformed: The Ancient Commentators and Their Influence. London: Duckworth.

Stock, Wiebke-Marie (2013). "Theurgy and Aesthetics in Dionysios the Areopagite." In Aesthetics and Theurgy in Byzantium, ed. Sergei Mariev and Wiebke-Marie Stock, 13-30. Berlin/New York: De Gruyter.

Struck, Peter (2001). "Pagan and Christian Theurgies." The Ancient World: Mystery Religions and Philosophy of Late Antiquity 32.1: 25-38.

Tollefsen, Torstein Theodor (2008). The Christocentric Cosmology of St Maximus the Confessor. Oxford: Oxford University Press.

Van den Berg, Robbert Maarten (2014). "The Gift of Hermes: The Neoplatonists on Language and Philosophy." In The Routledge Handbook of Neoplatonism, ed. Pauliina Remes and Svetla Slaveva-Griffin, 251-265. London/New York: Routledge.

Vanneste, Jean S.I. (1959). Le Mystère de Dieu. Essai sur la structure rationelle de la doctrine mystique du Pseudo-Denys l'Aréopagite. Brussels: Desclée de Brouwer.

Wear, Sarah Klitenic and John M. Dillon (2007). Dionysius the Areopagite and the Neoplatonist Tradition: Despoiling the Hellenes. Aldershot: Ashgate. 